\title{
Understanding Why Effective Fungicides Against Individual Soilborne Pathogens Are Ineffective with Soilborne Pathogen Complexes
}

\author{
Ming Pei You, ${ }^{1}$ Jay Ram Lamichhane, ${ }^{2}$ Jean-Noël Aubertot, ${ }^{2}$ and Martin J. Barbetti ${ }^{1, \dagger}$ \\ ${ }^{1}$ School of Agriculture and Environment and UWA Institute of Agriculture, The University of Western Australia, WA, 6009, \\ Australia \\ ${ }^{2}$ INRAE, Université Fédérale de Toulouse, UMR AGIR, CS52627, F-31326 Castanet-Tolosan Cedex, France
}

\begin{abstract}
Annual forage legumes across southern Australia continue to be devastated by soilborne diseases. Nine fungicide seed treatments (thiram, metalaxyl, iprodione, phosphonic acid, propamocarb, fluquinconazole, difenoconazole + metalaxyl, ipconazole + metalaxyl, sedaxane + difenoconazole + metalaxyl) and four foliar fungicide treatments (phosphonic acid, metalaxyl, propamocarb, iprodione) were tested on four subterranean clover cultivars against individual oomycete soilborne pathogens Pythium irregulare, Aphanomyces trifolii, and Phytophthora clandestina and the fungal pathogen Rhizoctonia solani. Best treatments were then further tested across southern Australia in 2 years of field experiments. Under controlled conditions, seed treatment with thiram was best against damping-off caused by $P$. irregulare across the four cultivars (Woogenellup, Riverina, Seaton Park, Meteora), while metalaxyl was the most effective for maximizing root and shoot weights. Against A. trifolii, metalaxyl, iprodione, difenoconazole + metalaxyl, ipconazole + metalaxyl, and sedaxane + difenoconazole + metalaxyl, all reduced damping-off; sedaxane + difenoconazole + metalaxyl, fluquinconazole, and ipconazole + metalaxyl all reduced lateral root disease across two or more cultivars; while iprodione, thiram, and sedaxane + difenoconazole + metalaxyl increased shoot dry weight. Against $P$. clandestina, metal-

$x$ cultivar interactions $(P<0.001)$. Under controlled conditions for foliar fungicide spray treatments, phosphonic acid was best at preventing productivity losses from $A$. trifolii, but was ineffective against $P$. clandestina, $P$. irregulare, or $R$. solani. Overall, controlled environment studies highlighted strong potential for utilizing seed treatments against individual pathogens to ensure seedling emergence and early survival, with seed and foliar sprays enhancing productivity by reducing seedling damping-off and root disease from individual pathogens. However, in field experiments over 2 years across southern Australia against naturally occurring soilborne pathogen complexes involving these same pathogens, only rarely did fungicide seed treatments or foliar sprays tested show any benefit. It is evident that currently available fungicide seed and/or foliar spray treatment options do not offer effective field mitigation of damping-off and root disease on annual forage legumes that underpin livestock production across southern Australia. The main reason for this failure relates to the unpredictable and ever-changing soilborne pathogen complexes involved, highlighting a need to now refocus away from fungicide options, particularly toward developing and deploying new host tolerances, but also in deploying appropriate cultural control options.
\end{abstract} axyl was the most effective in reducing tap and lateral root rot followed by ipconazole + metalaxyl or phosphonic acid for tap and lateral rot, respectively. Against $R$. solani, there were no effects of fungicides. For $P$. irregulare and $P$. clandestina, there were strong seed fungicide
Keywords: Rhizoctonia solani, Aphanomyces trifolii, Pythium irregulare, Phytophthora clandestina, root rot, damping-off, subterranean clover, Trifolium subterraneum, fungicides, forage legumes
Subterranean clover (Trifolium subterraneum) is an important component of agronomic systems worldwide, including regions with Mediterranean-type climates in Africa, Asia, Australia, Europe, North America, and South America (Nichols et al. 2014). It is particularly important in southern Australia where it has been sown across 29 million ha (Nichols et al. 2014), providing a valuable source of nutritious livestock feed and of nitrogen for cereal crops.

The Mediterranean climate can be described as "a transitionalregime temperate and dry tropical climate characterized by a concentration of rainfall in winter, occurrence of a distinct summer drought of variable length, high variability in precipitation from year to year, mild to warm or hot summers, and cool to cold winters with an absence of continental thermic excursion, and intensive solar radiation especially in summer" (Sivasithamparam 1993). Necrotrophic soilborne pathogens can dominate such regions for various reasons.

\section{${ }^{\dagger}$ Corresponding author: M. J. Barbetti; martin.barbetti@uwa.edu.au}

Funding: Meat and Livestock Australia (Project Grant No. B PSP 0005 "Managing Soil-borne Root Disease in Sub-clover Forages") provided the salary of the first author during these studies and also operational funding to conduct these studies.

The author(s) declare no conflict of interest.

Accepted for publication 9 September 2019

(C) 2020 The American Phytopathological Society
First, pathogen and crop cycles are forced to coincide by the opening seasonal rains after the long hot and dry summer-autumn period. Also, growth and survival of these soilborne pathogens is favored, while at the same time the plant host is predisposed to them, in these impoverished and nutrient-deficient soils (Sivasithamparam 1993). Hence, it is not surprising that necrotrophic fungal pathogens provide particular challenges to the productivity of forages and broad-acre crops in such regions. Such pathogens include the diverse range of soilborne pathogens that attack subterranean clover, resulting in severe damping-off and root disease in both seedlings (Barbetti et al. 1986a, b, 2006b, 2007; Wong 1986; Wong et al. 1984) and in mature subterranean clover swards (O'Rourke et al. 2009), greatly reducing forage productivity (Barbetti et al. 1986a; Gillespie 1983). The consequent widespread decline and failure of subterranean clover and also annual Medicago spp. forages to persist has led to devastating reductions in livestock carrying capacity and whole farm profitability across southern Australia (Barbetti et al. 1986b, 2006a; Nichols et al. 2014). This decline not only manifests as a decrease in the desirable legume component, but also as an increase in weed infestation (Barbetti and Jones 2011; Barbetti et al. 2006b). A survey undertaken across southern Australia in 2014 showed that the vast majority of the $>200$ samples taken had very severe levels of tap and lateral root disease on subterranean clover (with tap and lateral rot disease indices of 60 to $80 \%$ and 80 to $100 \%$, respectively) (Foster et al. 2017).

Soilborne pathogens of subterranean and other forage legumes occur as a pathogen complex, the most important of which include $P$ hytophthora clandestina, various Pythium species and $P$. irregulare in particular, Aphanomyces trifolii, Rhizoctonia solani, and to a lesser 
extent various Fusarium spp., particularly F. avenaceum (Barbetti et al. 2006a, b, 2007; Ma et al. 2008; Nichols et al. 2014; Wong et al. 1985a, b). While there have been many studies on forage legumes, particularly clovers, in relation to $P$. clandestina and $P$. irregulare, there have been relatively very few in relation to $R$. solani or A. trifolii (You et al. 2016).

Several different avenues have been deployed historically to try to manage soilborne disease in forage legumes. These include a strong focus on identifying and utilizing host resistance (Nichols et al. 2014). However, renovating forages, particularly 'semipermanent' forages, is not only expensive, but it is also challenging to establish new cultivars into pre-existing plant competition within existing forage systems (Nichols et al. 2014). It is also difficult to deal with multiple resistance-breaking races such as for $P$. clandestina (You et al. 2005b), and arduous to locate multiple resistances effective against two or more soilborne complex pathogens (Barbetti et al. 1986b; You et al. 2005a). Hence, there is a need to find alternative and more flexible root disease mitigation strategies for livestock producers, and to this aim You and Barbetti (2019) recently showed the benefits from altering forage species composition and the intensity of grazing, and by adding Rhizobium in situations affected by the soilborne pathogen complexes.

Another approach potentially offering flexibility for producers is use of seed treatments, some of which have resulted in both large increases in seedling survival, and decreases in the severity of decay of tap and lateral root systems of forage legumes with corresponding increases in forage productivity (Barbetti 1984a; Barbetti et al. 1987b; Smiley et al. 1986). Historically, treatments containing metalaxyl have been the most promising (Burnett et al. 1994; Hochman et al. 1990; Smiley et al. 1986), with thiram and propamocarb less effective (Barbetti et al. 1987b). In other studies, Barbetti (1984a) suggested that metalaxyl in particular but also thiram have potential for further development as possible commercial treatments for increasing seedling survival in susceptible forage legume cultivars being resown into areas affected by damping-off and root disease. However, there are contrasting reports (e.g., Barbetti 1983, 1984b, 1985) where seed treatments offered little or any benefit. This is particularly so where Barbetti (1985) used six rates of metalaxyl seed treatment at two field sites in Western Australia but without benefit. There has also been some limited historical evaluation of fungicide sprays; for example, Greenhalgh and Clarke (1985) and Greenhalgh et al. (1994) reported field applications of potassium phosphonate as effective in fields where $P$. clandestina predominated.

Recent studies have comprehensively defined the variability in terms of different pathogen components within the soilborne disease complexes affecting annual forage legumes (e.g., Foster et al. 2017). Other recent studies have also defined how the pathogens $P$. clandestina, $R$. solani, $P$. irregulare, and $A$. trifolii are differentially affected by a range of environmental and other factors including temperature, soil moisture, nutrition, and cultivar (You and Barbetti 2017a, 2017b; You et al. 2017b, 2018). Together, those studies highlighted a necessity to re-evaluate fungicide control options as a potential way to provide alternative, but flexible, options for producers to manage severe damping-off and root disease in forage legumes. The period of most severe damping-off and root disease coincides with the critical autumnwinter animal feed-gap across southern Australia (Foster et al. 2017). To this aim, we first tested a wide range of seed treatment and foliar spray options against the most important individual soilborne pathogens under controlled environmental conditions. Then, based on those findings, we field-evaluated the most promising of these options on producer properties across southern Australia over two growing seasons.

\section{Materials and Methods}

Controlled environment - seed treatment application. There were five separate controlled environment studies undertaken testing fungicide seed treatments. Fungicide seed treatments included the commercial formulations Dividend M (a.i. $92 \mathrm{~g} / \mathrm{liter}$ difenoconazole $+23 \mathrm{~g} /$ liter metalaxyl-M), Jockey (a.i. fluquinconazole $167 \mathrm{~g} /$ liter), Metalaxyl (a.i. $350 \mathrm{~g} /$ liter metalaxyl), Phos-Inject 200 (a.i. $200 \mathrm{~g}$ phosphonic acid/liter), Previcur (a.i. propamocarb $600 \mathrm{~g}$ a.i./liter), Rancona Dimension (a.i. $25 \mathrm{~g} /$ liter ipconazole +20 g/liter metalaxyl), Rovral (a.i. iprodione $250 \mathrm{~g}$ a.i./liter), SynA16874F (a.i. sedaxane + difenoconazole + metalaxyl but exact a.i. values commercial-in-confidence), and Thiram 800 (a.i. thiram $800 \mathrm{~g} / \mathrm{kg}$ ) (see Table 1 for additional details for manufacturer and rates of application to seed). Seeds were coated by placing into a glass beaker and thoroughly mixing to coat seeds evenly. All application rates chosen were the application rates recommended by the manufacturer, and details are shown in Table 1. One gram of seeds required $300 \mu \mathrm{l}$ of solution to wet/coat thoroughly, such that each fungicide was constituted to a total volume of $300 \mu \mathrm{l}$ (using distilled water as needed for dilution).

Controlled environment - foliar fungicide application. There were two separate controlled environment studies undertaken testing fungicide seed treatments. Fungicide foliar spray applications included the commercial formulations Metalaxyl (a.i. $350 \mathrm{~g} / \mathrm{liter}$ metalaxyl), Phos-Inject 200 (a.i. 200 g phosphonic acid/liter), Previcur (a.i. propamocarb $600 \mathrm{~g}$ a.i./liter), and Rovral (a.i. iprodione $250 \mathrm{~g}$ a.i./liter). Foliar spray treatments were applied to the pots of plants approximately two and a half weeks after sowing using a knapsack sprayer with a single hollow cone nozzle with a water volume of 200 liter ha ${ }^{-1}$.

Controlled environment - subterranean clover cultivars. Four cultivars of subterranean clover were used in these tests, viz. Woogenellup, Riverina, Seaton Park, and Meteora, as each of these has different levels of resistance to each of the four test pathogens. For example, Seaton Park is known to have greatest resistance to the majority of known races of $P$. clandestina, compared with the other cultivars. Woogenellup is susceptible to nearly all races of $P$. clandestina (You et al. $2005 \mathrm{~b}$ ) and is utilized as a universal susceptible control comparison for all soilborne root disease studies on subterranean clover (Barbetti et al. 2006b, 2007). Subterranean clover seeds were surface sterilized in $70 \%$ ethanol for $30 \mathrm{~s}$ to remove any seed-pathogen contamination; then scarified lightly with sandpaper to break dormancy and increase germination.

Controlled environment - general experimental conditions. All experiments were conducted in a controlled environment room with temperatures maintained at $18 / 13^{\circ} \mathrm{C}$ (day/night) with a 12 -h photoperiod and light intensity of $480 \mu \mathrm{M} \mathrm{m}^{-2} \mathrm{~s}^{-1}$. These temperatures were selected to mimic a temperature commonly seen in the field in Western Australia during the May-August period of the growing season when root disease is most prevalent in subterranean clover forages (Barbetti 1991b). Pots were watered to free-draining with deionized water daily (i.e., to $100 \%$ water holding capacity). A sand-based mix representing light soil type was used and consisted of $2.5 \mathrm{~m}^{3}$ fine composted pine bark, $1 \mathrm{~m}^{3}$ coco peat, $5 \mathrm{~m}^{3}$ washed river sand, $10 \mathrm{~kg}$ slow release fertilizer Osmoform NXT $22 \mathrm{~N}+2.2 \mathrm{P}_{2} \mathrm{O}_{5}+$ $9.1 \mathrm{~K}_{2} \mathrm{O}+1.2 \mathrm{Mg}+$ trace elements (Everris International B.V.), $10 \mathrm{~kg}$ Dolomite (CalMag), $5 \mathrm{~kg}$ gypsum clay breaker, $5 \mathrm{~kg}$ extra fine limestone, $4 \mathrm{~kg}$ iron hepta sulfate, and $1 \mathrm{~kg}$ iron chelate.

Controlled environment - pathogen isolates. For $P$. irregulare, isolate WAC4953 (Department of Primary Industries and Regional Development Western Australia, Culture Collection) was used because this isolate had been used extensively in research on seedling damping-off and root rot on subterranean clover forages in Western Australia and it is representative of the prevailing $P$. irregulare populations on crop and forage legumes in Western Australia (Li et al. 2014). This isolate had been stored as lyophilized cultures for some years and was revived onto fresh corn meal agar.

For $R$. solani, a single isolate of anastomosis group AG8 (ZG6; isolate WAC9086, Department of Primary Industries and Regional Development Western Australia, Culture Collection) was chosen for the current study, as You et al. (2008) had shown that this AG8 (ZG6) group caused the greatest death of legume seedlings across different genera (Hedysarum, Medicago, Ornithopus, and Trifolium) in a study that included eight different forage legume species (H. coronarium, M. polymorpha, O. compressus, O. sativus, $T$. dasyurum, T. michelianum, T. purpureum, and T. subterraneum), in comparison with ZG1-5 and ZG11, ZG1-4, and especially, ZG4. This isolate had been maintained as a lyophilized culture for approximately 10 years and was revived onto fresh potato dextrose agar. 
Table 1. Fungicide manufacturer, commercial product name, and active ingredient for: fungicide seed and foliar spray application a.i. rates as used in controlled environment experiments; fungicides and their application a.i. rates as seed and foliar treatments as used in field 2015 field experiments; fungicides and their application a.i. rates as used in field 2016 field experiments

\begin{tabular}{|c|c|}
\hline \multicolumn{2}{|l|}{ Controlled environment } \\
\hline Fungicide name (seed treatments) & $\begin{array}{l}\text { Application rate } \\
\quad \text { (a.i. per } 100 \mathrm{~kg} \text { seed })\end{array}$ \\
\hline $\begin{array}{l}\text { Dividend M (Syngenta: active ingredients } \\
92 \text { g/liter difenoconazole }+23 \text { g/liter } \\
\text { metalaxyl-M) }\end{array}$ & $65 \mathrm{ml}$ \\
\hline $\begin{array}{l}\text { Jockey (Bayer: active ingredient } \\
\text { fluquinconazole } 167 \mathrm{~g} / \text { liter) }\end{array}$ & $45 \mathrm{ml}$ \\
\hline $\begin{array}{l}\text { Metalaxyl (4Farmers Australia Pty Ltd: active } \\
\text { ingredient } 350 \mathrm{~g} / \text { liter metalaxyl) }\end{array}$ & $500 \mathrm{ml}$ \\
\hline $\begin{array}{l}\text { Phos-Inject } 200 \text { (David Grays: active } \\
\text { ingredient } 200 \mathrm{~g} \text { phosphonic acid/liter) }\end{array}$ & $1,000 \mathrm{ml}$ \\
\hline $\begin{array}{l}\text { Previcur (Bayer: active ingredient } \\
\text { propamocarb } 600 \mathrm{~g} \text { a.i./liter) }\end{array}$ & $720 \mathrm{~g}$ \\
\hline $\begin{array}{l}\text { Rancona Dimension (Chemtura: active } \\
\text { ingredients } 25 \mathrm{~g} / \text { liter ipconazole }+20 \mathrm{~g} / \\
\text { liter } \\
\text { metalaxyl) }\end{array}$ & $160 \mathrm{ml}$ \\
\hline $\begin{array}{l}\text { Rovral (FMC Australia: active ingredient } \\
\text { iprodione } 250 \mathrm{~g} \text { a.i./liter) }\end{array}$ & $80 \mathrm{ml}$ \\
\hline $\begin{array}{c}\text { Syn-A16874F (Syngenta: active ingredients } \\
\text { sedaxane + difenoconazole + metalaxyl) }\end{array}$ & $90 \mathrm{ml}$ \\
\hline $\begin{array}{l}\text { Thiram } 800 \text { (Grochem Australia: active } \\
\text { ingredient: thiram } 800 \mathrm{~g} / \mathrm{kg} \text { ) }\end{array}$ & $100 \mathrm{~g}$ \\
\hline Fungicide name (foliar spray) & $\begin{array}{l}\text { Application rate } \\
\text { (a.i. per ha) }\end{array}$ \\
\hline $\begin{array}{l}\text { Metalaxyl (4Farmers Australia Pty Ltd: active } \\
\text { ingredient } 350 \mathrm{~g} / \text { liter metalaxyl) }\end{array}$ & 0.5 liter \\
\hline $\begin{array}{l}\text { Phos-Inject } 200 \text { (David Grays: active } \\
\text { ingredient } 200 \text { g phosphonic acid/liter) }\end{array}$ & 0.3 liter \\
\hline $\begin{array}{l}\text { Previcur (Bayer: active ingredient } \\
\text { propamocarb } 600 \mathrm{~g} \text { a.i./liter) }\end{array}$ & 1.5 liter \\
\hline $\begin{array}{l}\text { Rovral (FMC Australia: active ingredient } \\
\text { iprodione } 250 \mathrm{~g} \text { a.i./liter) }\end{array}$ & $1 \mathrm{~kg}$ \\
\hline
\end{tabular}

\section{Field 2015}

\begin{tabular}{|c|c|}
\hline Fungicide name (seed treatments) ${ }^{\mathbf{a}}$ & $\begin{array}{l}\text { Application rate } \\
\text { (a.i. per } 100 \mathrm{~kg} \text { seed })\end{array}$ \\
\hline $\begin{array}{l}\text { Metalaxyl (4Farmers Australia Pty Ltd: active } \\
\text { ingredient } 350 \mathrm{~g} / \text { liter metalaxyl) }\end{array}$ & $500 \mathrm{ml}$ \\
\hline $\begin{array}{l}\text { Phos-Inject } 200 \text { (David Grays: active } \\
\text { ingredient } 200 \mathrm{~g} \text { phosphonic acid/liter) }\end{array}$ & $1,000 \mathrm{~g}$ \\
\hline $\begin{array}{l}\text { Rancona Dimension (Chemtura: active } \\
\text { ingredients } 25 \mathrm{~g} / \text { liter ipconazole }+20 \mathrm{~g} / \\
\text { liter } \\
\text { metalaxyl) }\end{array}$ & $160 \mathrm{ml}$ \\
\hline $\begin{array}{l}\text { Thiram } 800 \text { (Grochem Australia: active } \\
\text { ingredient: thiram } 800 \mathrm{~g} / \mathrm{kg} \text { ) }\end{array}$ & $100 \mathrm{~g}$ \\
\hline Fungicide name (foliar spray) & $\begin{array}{l}\text { Application rate } \\
\text { (a.i. per ha) }\end{array}$ \\
\hline $\begin{array}{l}\text { Metalaxyl (4Farmers Australia Pty Ltd: active } \\
\text { ingredient } 350 \mathrm{~g} / \text { liter metalaxyl) }\end{array}$ & 0.5 liter \\
\hline $\begin{array}{l}\text { Phos-Inject } 200 \text { (David Grays: active } \\
\text { ingredient } 200 \mathrm{~g} \text { phosphonic acid/liter) }\end{array}$ & 0.3 liter \\
\hline
\end{tabular}

\section{Field 2016}

\begin{tabular}{|c|c|}
\hline Fungicide name (seed treatments) & $\begin{array}{l}\text { Application rate } \\
\text { (a.i. per } 100 \mathrm{~kg} \text { seed) }\end{array}$ \\
\hline $\begin{array}{l}\text { Mixed (Metalaxyl + Phos-Inject } 200+\text { Thiram } \\
\quad+\text { Rancona Dimension) }\end{array}$ & $\begin{array}{l}\text { Individual rates } \\
\text { as in Field } 2015 \text { above }\end{array}$ \\
\hline $\begin{array}{l}\text { Salicylic acid (active ingredient } 5 \mathrm{mM}, \sim 690 \\
\left.\text { mg/liter } \mathrm{C}_{7} \mathrm{H}_{6} \mathrm{O}_{3}\right)\end{array}$ & 30 liters \\
\hline Fungicide name (foliar spray) & $\begin{array}{l}\text { Application rate } \\
\text { (a.i. per ha) }\end{array}$ \\
\hline $\begin{array}{l}\text { Metalaxyl (4Farmers Australia Pty Ltd: } \\
\text { active ingredient } 350 \mathrm{~g} / \text { liter metalaxyl) }\end{array}$ & 0.5 liter \\
\hline $\begin{array}{l}\text { Phos-Inject } 200 \text { (David Grays: active } \\
\text { ingredient } 200 \text { g phosphonic acid/liter) }\end{array}$ & 0.3 liter \\
\hline
\end{tabular}

a Tested both at the full and half rate recommended by the manufacturer.
For $P$. clandestina, a fresh isolate was used. The isolate was obtained from infested subterranean clover soils sampled from a region on the south coast of Western Australia where Phytophthora root disease and damping-off is prevalent. This was achieved using subterranean clover cv. Woogenellup as the 'bait species'. In brief, Woogenellup plants were grown in infested soil samples in a controlled environment room at $18 / 13^{\circ} \mathrm{C}$ (day/night), with a $12 / 12 \mathrm{~h}$ photoperiod; then pots were flooded for $1 \mathrm{~h}$ at 1 and 3 weeks and harvested 4 weeks after sowing. Harvested plant roots were thoroughly washed under running tap water to remove soil. Whole root systems were floated in petri dishes containing sterile distilled water and maintained in the dark in an incubator at $20^{\circ} \mathrm{C}$. Using a light microscope, individual $P$. clandestina zoosporangia were collected (at 24-48 h), using fine-tip tweezers, and placed directly onto petri dishes containing the antibiotic medium PARPH (Kellam and Coffey 1985 ) that is selective for Phytophthora spp. Colonies were counted after 2 and 3 days. $P$. clandestina cultures were then subcultured onto fresh lima bean agar (LBA) and grown for 1 week in preparation for inoculum production. One isolate of $P$. clandestina identified as "race 173" was selected for these studies by testing isolates across the seven standard subterranean clover host differentials (You et al. 2005b). Historically, this particular race was the prevailing race on subterranean clover in the southwest of Western Australia (You et al. 2005b) and more recently has been confirmed to be one of the most prevalent races across southern Australia (M. P. You and M. J. Barbetti, unpublished).

For A. trifolii, approximately $1 \mathrm{~kg}$ of topsoil was collected from known field sites infested with this pathogen in the high rainfall areas of southwest Western Australia. Soil was air-dried in a glasshouse at $25-30^{\circ} \mathrm{C}$ for 7 days and stored. When required, A. trifolii isolates were subsequently 'baited out' from the stored soil samples, using subterranean clover Woogenellup as the bait species. Plants were grown in soil samples in a controlled environment room where air temperature was maintained at $18 / 13^{\circ} \mathrm{C}$ (day/night), with a $12 / 12 \mathrm{~h}$ photoperiod and a light intensity of $480 \mu \mathrm{M} \mathrm{m}^{-2} \mathrm{~s}^{-1}$. Plants were flooded for $1 \mathrm{~h}$ at 1 and 3 weeks and harvested 4 weeks after sowing. Harvested plant roots were thoroughly washed under running tap water to remove soil. Whole root systems were floated in petri dishes containing sterile distilled water and maintained in the dark in an incubator at $20^{\circ} \mathrm{C}$. With the aid of a light microscope, individual $A$. trifolii zoosporangia were collected (at 24-48 h), using fine-tip tweezers, and placed directly onto petri dishes containing a modified MBV media (Pfender et al. 1984). A. trifolii cultures were then subcultured onto fresh cornmeal agar and grown for 1 week in preparation for inoculum production.

Controlled environment - production of pathogen inoculum and pathogen inoculation. Inoculum was prepared using a modified procedure from Barbetti (1989). In brief, $250 \mathrm{ml}$ Erlenmeyer flasks containing moistened sterile millet seeds (Panicum miliaceum) were inoculated separately with $2 \mathrm{~mm}$ squares taken from the leading edge of colonies growing on agar, and approximately 10 plugs were used to inoculate each flask. Millet seeds had been prepared by soaking $100 \mathrm{~g}$ of millet seeds in $100 \mathrm{ml}$ deionized water overnight in each flask and then water drained and autoclaved at $120^{\circ} \mathrm{C}$ for $20 \mathrm{~min}$ three times on each of three consecutive days. Flasks with inoculated millet seeds were hand shaken vigorously to homogenize inoculum with millet seeds every second day to ensure equal colonization. Inoculated millet seeds were incubated at $22^{\circ} \mathrm{C}$ for two (A. trifolii, $P$. irregulare, and $R$. solani) or three weeks ( $P$. clandestina). Colonized millet seeds then were used for inoculating soils.

For $P$. clandestina, $P$. irregulare, and A. trifolii, soil was mixed thoroughly with pathogen-colonized millet seeds at a rate of $0.5 \%$ (wt/wt) and used to fill pots. The control treatment for comparison were pots containing uninfested soil, but without any uncolonized millet seeds added, as uncolonized millet can readily 'bait-out' other nontarget soilborne pathogens present (Barbetti and Sivasithamparam 1987). Each variety of subterranean clover was sown at 5 seeds per pot at a depth of $10 \mathrm{~mm}$. Pots were $9 \mathrm{~cm} \times 9 \mathrm{~cm}$ square $\times 10 \mathrm{~cm}$ deep. For $R$. solani, each pot was inoculated with four colonized millet seeds evenly spaced on the surface of the soil then covered with a further 
1-cm layer of pasteurized potting mix. The inoculated pots were left in the growth room for 2 weeks before sowing to allow the pathogen to establish in the soil, a technique successfully utilized for inoculation of a range of Trifolium and other forage legumes (You et al. 2008). Pots are watered daily with deionized water to field capacity except for $R$. solani where pots were watered less often on every second day.

Controlled environment - disease, nodulation, and plant weight assessments. Germinated plants in each pot were counted to calculate emergence percentage at 2 weeks after sowing. Then, plants were harvested at 6 weeks after sowing, washed in running tap water to remove soil from roots, and scored for their level of root disease. Plants were then floated in shallow trays of deionized water and both tap and lateral roots rated individually for their disease severity using a 0 to 5 scale: score $0=$ root healthy, no discoloration; $1=<25 \%$ of root brown, no significant lesions; $2=25$ to $<50 \%$ of root brown, lesions toward base of tap root; $3=50$ to $<75 \%$ root brown, lesions mid tap root; $4=\geq 75 \%$ root affected, significant lesions toward crown; $5=$ plant dead and/or root system completely rotted off. The number of plants in each disease severity category was recorded. Then, all disease rating scores were transferred to a tap or lateral "Percent Disease Index (PDI)" based on McKinney (1923) where tap or lateral root PDI\% = (sum of all numerical grades $) \times 100 \div$ (total number of plants scored $\times$ maximum rating score).

Nodulation was assessed using a modified rating scheme from Corbin et al. (1977). The scoring system contained 6 nodulation categories based on nodule numbers and positioning: $0=$ no nodules on the crown or elsewhere; $1=$ no nodules on the crown with a few (1-10) elsewhere; 2 = a few crown nodules but no nodules elsewhere; 3 = many crown nodules $(>10)$ but no nodules elsewhere; $4=$ many crown nodules with a few nodules elsewhere; $5=$ many crown nodules with many nodules elsewhere. The average "Percent Nodulation Index (NI\%)" was then calculated as described above using the method described by McKinney (1923).

Shoots and roots from each pot were separated and dried at $60^{\circ} \mathrm{C}$ in an oven in separate paper bags for 3 days, then dry shoot and root weights were recorded and calculated as mg plant ${ }^{-1}$.

Controlled environment - confirmation of pathogen presence. In all experiments, Koch's postulates were successfully completed to confirm that the disease symptoms observed were in fact caused by the respective pathogen. Root segments (8-10), $2 \mathrm{~cm}$ in length, were dissected from diseased plants and floated in petri dishes containing sterile deionized water for $2-3$ days at $20^{\circ} \mathrm{C}$. Roots were examined microscopically every $12 \mathrm{~h}$ using a light microscope and the presence of each pathogen confirmed using characteristic hyphal, or oospore and zoosporangia for each pathogen.

Controlled environment - experimental design and analysis. For each pathogen, there were 10 treatments ( 9 fungicide treatments plus a nil treatment control comparison) $\times 2$ pathogen treatments (pathogen and a nil control comparison) $\times 4$ clover cultivars $\times 4$ replications; totaling 640 pots arranged in a complete randomized design. The whole experiment was fully repeated once under the

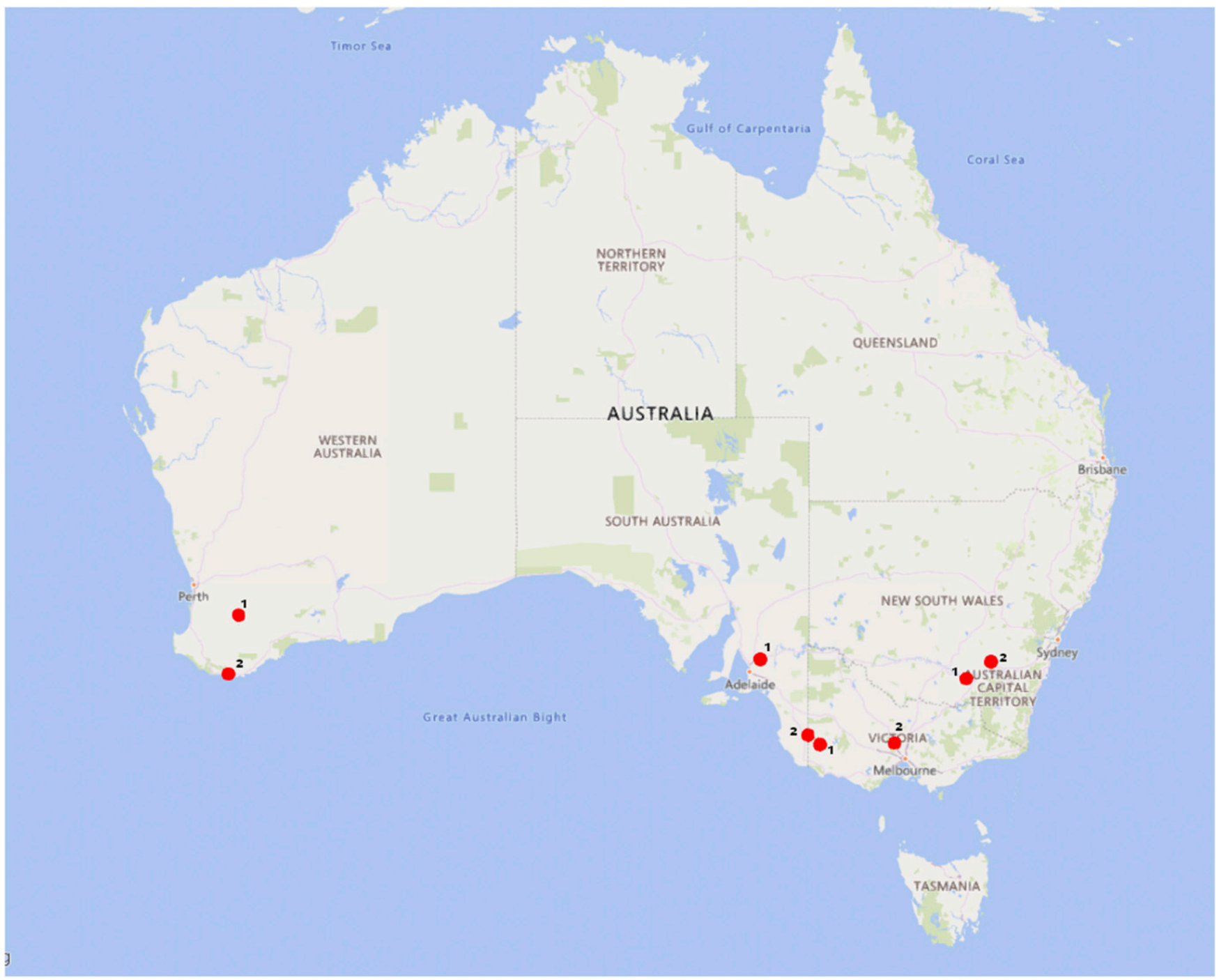

Fig. 1. Map of Australia showing the eight field sites (two each in Western Australia, South Australia, Victoria, and New South Wales) for fungicide seed and foliar spray testing in 2015 and 2016 growing seasons. 
same conditions. Analysis of variance (ANOVA) was conducted using GenStat (18th edition, Lawes Agricultural Trust). Normality of data and homogeneity of variances from each experiment were tested before conducting analyses. Data from the original and the repeat experiments were not significantly different $(P>0.05)$ using a $t$ test. Therefore, data from the original and repeat experiments were combined and reanalyzed together in relation to disease index of tap roots, disease index of lateral roots, root dry weight (RDW), and shoot dry weight (SDW) of seedlings. Therefore, the effect of different seed or spray fungicide treatments on the four different cultivars in the presence of each pathogen on emergence, tap root disease, lateral root disease, RDW, and SDW of seedlings were determined by analyses of variance, and subsequent multiple comparisons between treatments made using Fisher's protected least significant differences (LSD) at $P=0.05$.

Field studies 2015 and 2016 - site details. In each of 2015 and 2016, field experiments were conducted at eight locations across southern Australia (two experiments each in South Australia, Victoria, New South Wales, and Western Australia (Fig. 1) to evaluate the effects of various fungicide seed ( 4 and 2 different fungicides in 2015 and 2016, respectively) and two foliar sprays on the soilborne pathogens residing in these field locations. At each site in 2015, approximately 50 naturally occurring subterranean clover plants were sampled between 4 and 7 weeks after the opening seasonal rains. These plants were washed under running water and assessed for levels of tap and lateral root disease and nodulation using assessment scales described above. In addition, the percentage of tap and lateral roots showing presence of Pythium, Phytophthora, Rhizoctonia, Fusarium, or Aphanomyces at $12-72 \mathrm{~h}$ was calculated from floating roots in sterile distilled water, and the presence of each pathogen was confirmed using characteristic hyphal, conidia, or oospore and zoosporangia for each pathogen (Table 2). This was done to establish the nature of the soilborne pathogen complex present at each of these eight field sites at the commencement of these studies.

Field studies 2015 and 2016 - fungicide seed and foliar treatments. Seed treatments: In 2015, commercial formulations Metalaxyl (a.i. 350 g/liter metalaxyl), Phos-Inject 200 (a.i. 200 g phosphonic acid/liter), Rancona Dimension (a.i. $25 \mathrm{~g} / \mathrm{liter}$ ipconazole $+20 \mathrm{~g} /$ liter metalaxyl), and Thiram 800 (a.i. thiram 800 $\mathrm{g} / \mathrm{kg}$ ) were tested both at the full and half rate recommended by the manufacturer. (see details in Table 1); and in 2016, a mixed fungicide seed treatment (commercial formulations Metalaxyl + Phos-Inject 200 + Thiram + Rancona Dimension at same a.i. as above) and a salicylic acid (a.i. $5 \mathrm{mM}, \sim 690 \mathrm{mg} /$ liter $\mathrm{C}_{7} \mathrm{H}_{6} \mathrm{O}_{3}$ ) treatment were tested (see details in Table 1). Full details of manufacturer, and rates of application to seed are shown in Table 1 . We did not repeat the 2015 fungicide seed treatments in the 2016 growing season, as the efficacy of the 2015 treatments was so poor. For this reason, for 2016, the four different fungicide seed treatments from 2015 were combined into a single comprehensive seed treatment and tested, along with a single new treatment, salicylic acid. Foliar spray treatments: In both 2015 and 2016 (Table 1), the commercial formulations Metalaxyl (a.i. 350 g/liter metalaxyl) and Phos-Inject 200 (a.i. 200 g phosphonic acid/ liter) were tested. Full details of manufacturer and rates of foliar application are shown in Table 1. Cultivar: The universally susceptible cv. Woogenellup was used for all field experiments in both years. Field plots: For all seed and spray treatments, plots were $1 \mathrm{~m}$ rows at $30 \mathrm{~cm}$ spacing, and there were 10 row-replications per each treatment. A nil comparison control treatment was also included in all studies. Seed was sown by hand at approximately $1-2 \mathrm{~cm}$ depth by making a small groove in the soil, planting, and covering seed with minimal soil disturbance. Foliar spray treatments were applied to the single rows of plants approximately 6 weeks after sowing using a knapsack sprayer with a single hollow cone nozzle, with a water volume of 200 liters $\mathrm{ha}^{-1}$.

Field studies 2015 and 2016 - disease and plant weight assessments. Germinated plants in each row plot were counted at approximately 6-7 weeks after sowing to calculate emergence percentage. At that time, approximately one-third of plants were harvested per row for seed treatment rows, washed in running tap water to remove soil from roots, and scored for their level of root disease. Subsequently, at approximately 16-18 weeks after sowing, remaining plants in seed treatment rows and all plants in foliar spray treatment rows were harvested and similarly treated. Plants were then floated in shallow trays of deionized water and both tap and lateral roots rated individually for their disease severity using the

Table 2. Tap (TDI\%) and lateral (LDI\%) percent root disease index, percent nodulation index (NI\%), and the percentage of roots on field plants sampled in 2015 showing presence of Pythium, Phytophthora, Rhizoctonia, Fusarium, or Aphanomyces at each of the eight field sites used for field studies in 2015 and 2016 (see Figure 1 for locations)

\begin{tabular}{|c|c|c|c|c|c|c|c|c|}
\hline Site no. & TDI\% & LDI\% & NI\% & Pythium\% & Phytophthora\% & Rhizoctonia \% & Fusarium\% & Aphanomyces\% \\
\hline WA 1 & 22 & 38 & 20 & 8 & 0 & 35 & 5 & 0 \\
\hline WA 2 & 20 & 80 & 0 & 8 & 40 & 0 & 0 & 0 \\
\hline SA 1 & 80 & 80 & 30 & 10 & 0 & 20 & 5 & 0 \\
\hline SA 2 & 68 & 72 & 16 & 8 & 0 & 20 & 5 & 0 \\
\hline Vic. 1 & 70 & 78 & 24 & 17 & 0 & 20 & 6 & 10 \\
\hline Vic. 2 & 70 & 67 & 20 & 25 & 0 & 15 & 5 & 0 \\
\hline NSW 1 & 73 & 57 & 30 & 8 & 0 & 20 & 5 & 0 \\
\hline NSW 2 & 30 & 47 & 37 & 8 & 10 & 20 & 5 & 0 \\
\hline
\end{tabular}

Table 3. Controlled Experiment 1: Seed treatments against Pythium irregulare. Statistical main effects and interactions $(P$ and LSD values).

\begin{tabular}{|c|c|c|c|c|c|c|c|c|c|c|}
\hline \multirow[b]{2}{*}{ Main effects } & \multicolumn{2}{|c|}{ Emergence \% } & \multicolumn{2}{|c|}{ Root disease index } & \multicolumn{2}{|c|}{$\begin{array}{l}\text { Root dry weight } \\
(\mathrm{mg})\end{array}$} & \multicolumn{2}{|c|}{$\begin{array}{l}\text { Shoot dry weight } \\
(\mathbf{m g})\end{array}$} & \multicolumn{2}{|c|}{ Nodulation index } \\
\hline & $\begin{array}{c}P \\
\text { value }\end{array}$ & $\begin{array}{c}\text { LSD = } \\
0.05\end{array}$ & $\begin{array}{c}P \\
\text { value }\end{array}$ & $\begin{array}{c}\text { LSD }= \\
0.05\end{array}$ & $\begin{array}{c}P \\
\text { value }\end{array}$ & $\begin{array}{c}\text { LSD = } \\
0.05\end{array}$ & $\begin{array}{c}P \\
\text { value }\end{array}$ & $\begin{array}{c}\mathrm{LSD}= \\
0.05\end{array}$ & $\begin{array}{c}P \\
\text { value }\end{array}$ & $\begin{array}{l}\mathrm{LSD}= \\
\mathbf{0 . 0 5}\end{array}$ \\
\hline Fungicide seed treatment & $<0.001$ & 6.669 & $<0.001$ & 3.663 & $<0.001$ & 2.573 & NS & - & NS & - \\
\hline Inoculation & $<0.001$ & 2.983 & $<0.001$ & 1.638 & $<0.001$ & 1.151 & $<0.001$ & 1.741 & NS & - \\
\hline Cultivars & $<0.001$ & 4.218 & NS & - & $<0.001$ & 1.627 & $<0.001$ & 2.462 & 0.043 & 1.866 \\
\hline Fungicide seed treatment $\times$ inoculation & $<0.001$ & 9.432 & $<0.001$ & 5.18 & $<0.001$ & 3.639 & $<0.001$ & 5.506 & $<0.001$ & 4.173 \\
\hline Fungicide seed treatment $\times$ cultivars & $<0.001$ & 13.339 & 0.009 & 7.326 & $<0.001$ & 5.146 & $<0.001$ & 7.786 & NS & - \\
\hline Inoculation $\times$ cultivars & $<0.001$ & 5.965 & NS & - & $<0.001$ & 2.302 & NS & - & 0.006 & 2.639 \\
\hline $\begin{array}{l}\text { Fungicide seed treatment } \times \text { inoculation } \times \\
\text { cultivars }\end{array}$ & NS & - & 0.005 & 10.36 & 0.012 & 7.278 & 0.027 & 11.011 & NS & - \\
\hline
\end{tabular}


same 0 to 5 described above, with disease rating scores transferred to a tap or lateral PDI based on McKinney (1923). Shoots and roots from each pot were separated and oven-dried at $60^{\circ} \mathrm{C}$ as described earlier and dry shoot and root weights calculated as mg plant $^{-1}$.
Field studies 2015 and 2016 - experimental design and analysis. Treatment rows were arranged in a randomized block design with 10 replications and repeated at 8 sites across southern Australia in both 2015 and 2016 seasons. Analysis of variance (ANOVA) was conducted using GenStat (18th edition, Lawes Agricultural Trust).

Table 4. Controlled Experiment 1: Seed treatments against Pythium irregulare. Effect of fungicide seed treatments on emergence (\%), root rot disease index, root dry weight $(\mathrm{mg})$, shoot dry weight $(\mathrm{mg})$, and nodulation index. Means are shown in italics.

\begin{tabular}{|c|c|c|c|c|c|c|c|c|c|c|}
\hline & \multirow{2}{*}{ Cultivars } & \multicolumn{2}{|c|}{ Meteora } & \multicolumn{2}{|c|}{ Riverina } & \multicolumn{2}{|c|}{ Seaton Park } & \multicolumn{2}{|c|}{ Woogenellup } & \multirow[b]{3}{*}{ Mean } \\
\hline & & \multirow[b]{2}{*}{ Nil } & \multirow{2}{*}{$\begin{array}{c}P . \\
\text { irregulare }\end{array}$} & \multirow[b]{2}{*}{ Nil } & \multirow{2}{*}{$\begin{array}{c}P . \\
\text { irregulare }\end{array}$} & \multirow[b]{2}{*}{ Nil } & \multirow{2}{*}{$\begin{array}{c}P . \\
\text { irregulare }\end{array}$} & \multirow[b]{2}{*}{ Nil } & \multirow{2}{*}{$\begin{array}{c}P . \\
\text { irregulare }\end{array}$} & \\
\hline & Inoculum & & & & & & & & & \\
\hline \multirow[t]{10}{*}{ Emergence (\%) } & Dividend & 75.00 & 45.00 & 80.00 & 72.50 & 90.00 & 85.00 & 72.50 & 85.00 & 75.63 \\
\hline & Fluquinconazole & 65.00 & 22.50 & 80.00 & 75.00 & 90.00 & 100.00 & 75.00 & 87.50 & 74.38 \\
\hline & Metalaxyl & 65.00 & 37.50 & 72.50 & 82.50 & 75.00 & 85.00 & 67.50 & 72.50 & 69.69 \\
\hline & Nil & 80.00 & 52.50 & 75.00 & 47.50 & 87.50 & 82.50 & 80.00 & 70.00 & 71.88 \\
\hline & Phosphonic acid & 57.50 & 42.50 & 60.00 & 30.00 & 45.00 & 10.00 & 60.00 & 35.00 & 42.50 \\
\hline & Propamocarb & 75.00 & 72.50 & 82.50 & 72.50 & 87.50 & 92.50 & 77.50 & 67.50 & 78.44 \\
\hline & Ipconazole + metalaxyl & 72.50 & 60.00 & 85.00 & 95.00 & 95.00 & 90.00 & 92.50 & 90.00 & 85.00 \\
\hline & Iprodione & 80.00 & 90.00 & 90.00 & 67.50 & 95.00 & 95.00 & 80.00 & 87.50 & 85.63 \\
\hline & Sedaxane + difenoconazole + metalaxyl & 80.00 & 72.50 & 77.50 & 82.50 & 95.00 & 97.50 & 80.00 & 95.00 & 85.00 \\
\hline & Thiram & 80.00 & 82.50 & 92.50 & 90.00 & 95.00 & 97.50 & 80.00 & 87.50 & 88.13 \\
\hline Mean & & 73.00 & 57.75 & 79.50 & 71.50 & 85.50 & 83.50 & 76.50 & 77.75 & 75.63 \\
\hline Root disease index & Dividend & 0.00 & 58.33 & 0.00 & 56.10 & 0.00 & 51.53 & 0.00 & 52.92 & 27.36 \\
\hline & Fluquinconazole (Jockey) & 5.83 & 50.48 & 0.00 & 61.67 & 0.00 & 46.67 & 0.00 & 50.00 & 26.83 \\
\hline & Metalaxyl & 0.00 & 26.39 & 0.00 & 21.46 & 0.00 & 35.42 & 0.00 & 33.33 & 14.58 \\
\hline & Nil & 0.00 & 68.75 & 0.00 & 67.70 & 0.00 & 56.67 & 0.00 & 55.56 & 31.09 \\
\hline & Phosphonic acid & 0.00 & 54.17 & 0.00 & 45.11 & 0.00 & 61.31 & 0.00 & 49.72 & 26.29 \\
\hline & Propamocarb & 0.00 & 52.15 & 0.00 & 73.82 & 0.00 & 61.94 & 0.00 & 62.15 & 31.26 \\
\hline & Ipconazole + metalaxyl & 0.00 & 60.42 & 0.00 & 56.39 & 0.00 & 67.72 & 0.00 & 61.87 & 30.80 \\
\hline & Iprodione & 0.00 & 52.50 & 0.00 & 47.01 & 0.00 & 61.46 & 0.00 & 53.75 & 26.84 \\
\hline & Sedaxane + difenoconazole + metalaxyl & 0.00 & 66.04 & 0.00 & 62.29 & 0.00 & 55.62 & 0.00 & 41.67 & 28.20 \\
\hline & Thiram & 0.00 & 66.88 & 0.00 & 62.29 & 0.00 & 52.05 & 0.00 & 54.24 & 29.43 \\
\hline Mean & & 0.58 & 55.61 & 0.00 & 55.38 & 0.00 & 55.04 & 0.00 & 51.52 & 27.27 \\
\hline Root dry weight & Dividend & 28.14 & 27.54 & 31.14 & 17.28 & 22.79 & 17.95 & 27.78 & 19.68 & 24.04 \\
\hline & Fluquinconazole & 35.69 & 24.36 & 21.9 & 14.12 & 13.22 & 16.27 & 30.17 & 31.36 & 23.39 \\
\hline & Metalaxyl & 27.72 & 36.85 & 27.04 & 22.14 & 11.77 & 16.05 & 30.19 & 26.94 & 24.84 \\
\hline & Nil & 28.17 & 21.35 & 26.5 & 15.18 & 19.28 & 13.34 & 33.04 & 24.29 & 22.64 \\
\hline & Phosphonic acid & 28.41 & 23.47 & 32.27 & 17.49 & 28.19 & 29.96 & 25.91 & 27.22 & 26.62 \\
\hline & Propamocarb & 28.94 & 17.3 & 27.76 & 19.3 & 22.63 & 13.76 & 31.94 & 30.99 & 24.08 \\
\hline & Ipconazole + metalaxyl & 24.37 & 23.94 & 33.35 & 12.85 & 23.65 & 13.79 & 20.51 & 16.8 & 21.16 \\
\hline & Iprodione & 25.97 & 18.75 & 26.52 & 16.34 & 22.33 & 13.23 & 29.84 & 27.39 & 22.55 \\
\hline & Sedaxane + difenoconazole + metalaxyl & 26.42 & 10.7 & 30.99 & 15.03 & 25.2 & 12.27 & 27.92 & 22.93 & 21.43 \\
\hline & Thiram & 30.9 & 14.62 & 24.02 & 13.06 & 24.35 & 11.07 & 31.08 & 23.33 & 21.55 \\
\hline Mean & & 28.47 & 21.89 & 28.15 & 16.28 & 21.34 & 15.77 & 28.84 & 25.09 & 23.23 \\
\hline Shoot dry weight & Dividend & 42.71 & 53.28 & 45.86 & 28.28 & 31.86 & 28.18 & 40.22 & 31.74 & 37.77 \\
\hline & Fluquinconazole & 49.19 & 44.44 & 30.84 & 26.00 & 21.77 & 22.30 & 48.79 & 45.78 & 36.14 \\
\hline & Metalaxyl & 47.16 & 51.68 & 45.68 & 38.05 & 20.70 & 23.27 & 44.20 & 45.71 & 39.56 \\
\hline & Nil & 53.57 & 35.57 & 36.94 & 25.32 & 29.53 & 17.58 & 52.05 & 35.28 & 35.73 \\
\hline & Phosphonic acid & 43.47 & 35.44 & 43.67 & 24.11 & 33.05 & 45.80 & 46.63 & 33.45 & 38.20 \\
\hline & Propamocarb & 48.27 & 30.99 & 41.15 & 30.74 & 35.98 & 17.51 & 47.99 & 43.74 & 37.05 \\
\hline & Ipconazole + metalaxyl & 42.44 & 33.57 & 41.02 & 28.18 & 34.88 & 21.96 & 38.09 & 29.52 & 33.71 \\
\hline & Iprodione & 45.43 & 32.80 & 42.46 & 27.67 & 32.00 & 18.67 & 46.13 & 40.06 & 35.65 \\
\hline & Sedaxane + difenoconazole + metalaxyl & 42.66 & 24.19 & 46.79 & 30.00 & 33.41 & 16.76 & 42.18 & 35.68 & 33.96 \\
\hline & Thiram & 48.49 & 27.63 & 39.81 & 24.85 & 35.10 & 16.87 & 41.02 & 36.98 & 33.84 \\
\hline Mean & & 46.34 & 36.96 & 41.42 & 28.32 & 30.83 & 22.89 & 44.73 & 37.79 & 36.16 \\
\hline Nodulation index & Dividend & 10.38 & 4.75 & 3.12 & 9.78 & 12.83 & 8.50 & 7.67 & 6.75 & 7.97 \\
\hline & Fluquinconazole & 5.00 & 6.36 & 7.75 & 5.92 & 5.12 & 10.50 & 0.50 & 6.13 & 5.91 \\
\hline & Metalaxyl & 3.75 & 10.00 & 3.75 & 9.08 & 4.67 & 6.00 & 9.58 & 14.58 & 7.68 \\
\hline & Nil & 11.29 & 2.08 & 2.91 & 6.90 & 5.38 & 7.38 & 8.13 & 9.75 & 6.73 \\
\hline & Phosphonic acid & 16.25 & 0.00 & 5.95 & 0.03 & 12.92 & 0.00 & 0.00 & 3.35 & 4.81 \\
\hline & Propamocarb & 5.00 & 4.75 & 7.71 & 8.00 & 13.63 & 4.12 & 2.50 & 7.29 & 6.63 \\
\hline & Ipconazole + metalaxyl & 10.25 & 1.67 & 11.25 & 6.50 & 13.13 & 8.30 & 2.25 & 8.88 & 7.78 \\
\hline & Iprodione & 7.92 & 3.87 & 1.96 & 3.50 & 8.50 & 10.50 & 1.75 & 6.87 & 5.61 \\
\hline & Sedaxane + difenoconazole + metalaxyl & 2.62 & 5.63 & 3.75 & 14.79 & 2.00 & 6.38 & 0.00 & 0.00 & 4.40 \\
\hline & Thiram & 1.87 & 6.62 & 2.50 & 4.21 & 2.50 & 11.13 & 0.50 & 2.75 & 4.01 \\
\hline Mean & & 7.43 & 4.57 & 5.07 & 6.87 & 8.07 & 7.28 & 3.29 & 6.64 & 6.15 \\
\hline
\end{tabular}


Normality of data and homogeneity of variances from each experiment were tested before conducting analyses. Comparisons between treatments were made using Fisher's protected least significant differences (LSD) at $P=0.05$.

\section{Results}

Controlled environment Experiment 1: seed fungicides against $P$. irregulare. Emergence rate. There were significant differences in percent emergence in relation to fungicide seed treatments, pathogen inoculation, and cultivars $\left(P<0.001, \mathrm{LSD}_{0.05}=6.67 ; P<0.001\right.$, $\mathrm{LSD}_{0.05}=2.98$; and $P<0.001, \mathrm{LSD}_{0.05}=4.22$, respectively). There were significant interactions between fungicide seed treatment with pathogen inoculation, between fungicide seed treatment with cultivars, and between inoculation with cultivars $\left(P<0.001, \mathrm{LSD}_{0.05}=\right.$ 9.43; $P<0.001, \mathrm{LSD}_{0.05}=13.34$; and $P<0.001, \mathrm{LSD}_{0.05}=5.96$, respectively) (Table 3 ). Thiram showed the best protection from preemergence damping-off for all four cultivars tested in comparison with other tested fungicides and the 'nil disease' control. Iprodione gave high protection for Meteora, Seaton Park, and Woogenellup but not Riverina. Sedaxane + difenoconazole + metalaxyl and ipconazole + metalaxyl gave good protection for Riverina, Seaton Park, and Woogenellup but not for Meteora. Phosphonic acid gave the lowest protection for all the cultivars tested against $P$. irregulare pre-emergence damping-off, followed by metalaxyl which gave second lowest protection (Table 4).

Root disease severity. There were significant differences in terms of root disease index in relation to fungicide seed treatments and also to pathogen inoculation $\left(P<0.001, \mathrm{LSD}_{0.05}=3.66 ; P<0.001\right.$, $\mathrm{LSD}_{0.05}=1.64$, respectively). There was significant interaction between fungicide seed treatments with pathogen inoculation and between fungicide seed treatments with cultivars $(P<0.001$, $\mathrm{LSD}_{0.05}=5.18 ; P=0.009, \mathrm{LSD}_{0.05}=7.33$, respectively). There was a three-way interaction between fungicide seed treatment, inoculation, and cultivars $\left(P=0.005, \mathrm{LSD}_{0.05}=10.36\right)($ Table 3$)$. Metalaxyl was the best seed treatment among nine tested fungicides against $P$. irregulare root rot disease across all four cultivars tested. Phosphonic acid, fluquinconazole, and iprodione were the second best, while propamocarb had the least effect on reducing levels of root rot disease (Table 4).

Root dry weight and shoot dry weight. In relation to root dry weight, there were significant differences between fungicide seed treatments, pathogen inoculation, and cultivars $\left(P<0.001, \mathrm{LSD}_{0.05}=\right.$ $2.57 ; P<0.001, \mathrm{LSD}_{0.05}=1.15$; and $P<0.001, \mathrm{LSD}_{0.05}=1.63$, respectively). There were significant interactions between fungicide seed treatment with inoculation, between fungicide seed treatment with cultivars, and between inoculation with cultivars $\left(P<0.001, \mathrm{LSD}_{0.05}=\right.$ 3.64; $P<0.001, \mathrm{LSD}_{0.05}=5.15$; and $P<0.001, \mathrm{LSD}_{0.05}=2.30$, respectively). There was a three-way interaction between fungicide seed treatment, inoculation, and cultivars $\left(P=0.012, \mathrm{LSD}_{0.05}=7.28\right)$ (Table 3$)$. In relation to shoot dry weight, there were significant effects from pathogen inoculation and for cultivars $\left(P<0.001, \mathrm{LSD}_{0.05}=1.74\right.$; and $P$ $<0.001, \mathrm{LSD}_{0.05}=2.46$, respectively). There were also significant interactions between fungicide seed treatment with inoculation, and between fungicide seed treatment with cultivars $\left(P<0.001, \mathrm{LSD}_{0.05}=\right.$ 5.51; and $P<0.001, \mathrm{LSD}_{0.05}=7.79$, respectively). There was also a three-way interaction between fungicide seed treatment, inoculation, and cultivars $\left(P=0.03, \mathrm{LSD}_{0.05}=11.01\right)($ Table 3$)$. Phosphonic acid and metalaxyl were the best for maximizing root and shoot dry weights, while ipconazole + metalaxyl, sedaxane + difenoconazole + metalaxyl, and thiram were the least effective in terms of root and shoot dry weights (Table 4).

Controlled environment Experiment 2: foliar sprays against $\boldsymbol{P}$. irregulare. Fungicide foliar treatments had no significant effect on levels of tap or lateral root rot, nor on root or shoot dry weight, nor on level of nodulation (data not shown).

Controlled environment Experiment 3: seed fungicides against A. trifolii. Emergence. For emergence, there were significant differences between fungicide seed treatments and between cultivars $(P=$ $0.02, \mathrm{LSD}_{0.05}=5.99$; and $P<0.001, \mathrm{LSD}_{0.05}=3.79$, respectively). There were significant interactions between fungicide seed treatment with inoculation; between fungicide seed treatment with cultivars; and between inoculation with cultivars $\left(P=0.01, \mathrm{LSD}_{0.05}=8.47\right.$; $P<0.001, \mathrm{LSD}_{0.05}=11.98$; and $P<0.001, \mathrm{LSD}_{0.05}=5.36$, respectively) (Table 5). Iprodione, difenoconazole + metalaxyl, and fluquinconazole showed best protection from pre-emergence damping-off in Meteora in comparison with other tested fungicides. Ipconazole + metalaxyl, difenoconazole + metalaxyl, and sedaxane + difenoconazole + metalaxyl gave high protection for Riverina, while sedaxane + difenoconazole + metalaxyl and difenoconazole + metalaxyl showed best protection for Seaton Park. Thiram and difenoconazole + metalaxyl showed good protection for Woogenellup (Table 6).

Percent disease indices. Fungicide seed treatments had no effect on severity of tap root disease but had significant effect on lateral root disease $\left(P=0.041, \mathrm{LSD}_{0.05}=7.88\right)$. Inoculation, cultivar, and their interaction were significant in terms of both tap root disease $(P<$ $0.001, \mathrm{LSD}_{0.05}=3.42 ; P<0.001, \mathrm{LSD}_{0.05}=4.84$; and $P=0.011$, $\mathrm{LSD}_{0.05}=6.85$, respectively $)$ and also lateral root disease $(P<$ $0.001, \mathrm{LSD}_{0.05}=3.52 ; P<0.001, \mathrm{LSD}_{0.05}=4.98$; and $P=0.018$, $\mathrm{LSD}_{0.05}=7.05$, respectively) (Table 5). Overall, metalaxyl was the best seed treatment against $A$. trifolii lateral root rot disease across all four cultivars tested. Cultivars Meteora and Riverina showed least lateral root disease with fluquinconazole, while Seaton Park and Woogenellup showed least lateral root disease with thiram or ipconazole + metalaxyl (Table 6).

Root dry weight and shoot dry weight. There were no significant effects on root dry weight from fungicide seed treatment, pathogen inoculation, or cultivars, but there were significant effects on shoot dry weight from fungicide seed treatment, from different cultivars, and there was significant interaction of fungicide seed treatment with cultivars $\left(P=0.038, \mathrm{LSD}_{0.05}=3.89 ; P<0.001, \mathrm{LSD}_{0.05}=2.46\right.$; and $P=0.001, \mathrm{LSD}_{0.05}=7.77$, respectively) (Table 5). Overall, thiram and iprodione were best at maximizing shoot dry weights, while difenoconazole + metalaxyl and ipconazole + metalaxyl were the least effective in terms of shoot dry weight (Table 6).

Controlled environment Experiment 4: foliar fungicides against $\boldsymbol{A}$. trifolii. Fungicide foliar treatments had no significant effect on percent germination but did significantly affect both tap and lateral root disease level and also root and shoot dry weights (Table 7). Different cultivars showed significant differences in terms of germination, tap and lateral root disease levels, and also in terms of root and shoot dry weights (Table 8). Overall, phosphonic acid was best for protecting against both tap and lateral root disease caused by

Table 5. Controlled Experiment 3: Seed treatments against Aphanomyces trifolii. Statistical main effects and interactions ( $P$ and LSD values)

\begin{tabular}{|c|c|c|c|c|c|c|c|c|}
\hline \multirow[b]{2}{*}{ Main effects } & \multicolumn{2}{|c|}{ Emergence \% } & \multicolumn{2}{|c|}{ Tap root disease index } & \multicolumn{2}{|c|}{$\begin{array}{c}\text { Lateral root disease } \\
\text { index }\end{array}$} & \multicolumn{2}{|c|}{ Shoot dry weight (mg) } \\
\hline & $P$ value & LSD $=0.05$ & $P$ value & LSD $=\mathbf{0 . 0 5}$ & $P$ value & LSD $=\mathbf{0 . 0 5}$ & $P$ value & LSD $=\mathbf{0 . 0 5}$ \\
\hline Fungicide seed treatment & 0.023 & 5.992 & NS & NS & 0.041 & 7.881 & 0.038 & 3.886 \\
\hline Inoculation & NS & - & $<0.001$ & 3.424 & $<0.001$ & 3.525 & NS & - \\
\hline Cultivars & $<0.001$ & 3.79 & $<0.001$ & 4.842 & $<0.001$ & 4.985 & $<0.001$ & 2.458 \\
\hline Fungicide seed treatment $\times$ inoculation & 0.01 & 8.474 & NS & - & NS & - & NS & - \\
\hline Fungicide seed treatment $\times$ cultivars & $<0.001$ & 11.984 & NS & - & NS & - & 0.001 & 7.772 \\
\hline Inoculation $\times$ cultivars & $<0.001$ & 5.359 & 0.011 & 6.848 & 0.018 & 7.049 & NS & - \\
\hline
\end{tabular}


A. trifolii, followed by propamocarb; and effects were similar in relation to dry root weights (Table 8). For shoot dry weight, iprodione was best, followed by phosphonic acid and propamocarb; while metalaxyl was the least effective spray fungicide for protecting tap and lateral roots from disease caused by A. trifolii (Table 8 ).

Controlled environment Experiment 5: seed fungicides against $\boldsymbol{P}$. clandestina. Fungicide treatments overall significantly reduced tap and lateral root disease, and there were significant interactions between fungicides with cultivar in relation to both tap and lateral root disease (Tables 9 and 10, Fig. 2A and B). For tap root disease, metalaxyl was most effective, followed by ipconazole + metalaxyl. There was a strong interaction of fungicide with cultivar, for example where phosphonic acid significantly reduced tap root disease on Meteora but not on Riverina, and where metalaxyl and ipconazole + metalaxyl reduced tap root disease only on Meteora and Riverina. The least tap root disease occurred on Seaton Park, which is highly resistant to $P$. clandestina, and there was overall no benefit from utilizing fungicides on this cultivar (Table 10, Fig. 2A). In relation to lateral root disease, metalaxyl was again the best fungicide across Meteora, Riverina, and Woogenellup, followed by phosphonic acid across the same cultivars, then ipconazole + metalaxyl but only for Riverina and Woogenellup (Table 10, Fig. 2B).

Table 6. Controlled Experiment 3: Seed treatments against Aphanomyces trifolii. Effect of fungicide seed treatments on emergence (\%), tap root rot disease index, lateral root rot disease index, and shoot dry weight (mg). Means are shown in italics.

\begin{tabular}{|c|c|c|c|c|c|c|c|c|c|}
\hline \multirow[b]{2}{*}{$\frac{\text { Cultivars }}{\text { Inoculum }}$} & \multicolumn{2}{|r|}{ Meteora } & \multicolumn{2}{|r|}{ Riverina } & \multicolumn{2}{|c|}{ Seaton Park } & \multicolumn{2}{|c|}{ Woogenellup } & \multirow[b]{2}{*}{ Mean } \\
\hline & Nil & $\begin{array}{c}\text { Aphanomyces } \\
\text { trifolii }\end{array}$ & Nil & $\begin{array}{c}\text { Aphanomyces } \\
\text { trifolii }\end{array}$ & Nil & $\begin{array}{l}\text { Aphanomyces } \\
\text { trifolii }\end{array}$ & \multirow[t]{2}{*}{ Nil } & $\begin{array}{c}\text { Aphanomyces } \\
\text { trifolii }\end{array}$ & \\
\hline & \multicolumn{8}{|c|}{ Emergence rate (\%) } & \\
\hline Nil & 92.5 & 85.0 & 90.0 & 85.0 & 92.5 & 82.5 & 67.5 & 72.5 & 83.4 \\
\hline Dividend & 85.0 & 90.0 & 75.0 & 85.0 & 85.0 & 92.5 & 72.5 & 87.5 & 84.1 \\
\hline Fluquinconazole & 87.5 & 90.0 & 67.5 & 77.5 & 92.5 & 75.0 & 85.0 & 82.5 & 82.2 \\
\hline Metalaxyl & 82.5 & 82.5 & 72.5 & 67.5 & 90.0 & 77.5 & 87.5 & 80.0 & 80.0 \\
\hline Phosphonic acid & 77.5 & 80.0 & 65.0 & 70.0 & 92.5 & 77.5 & 85.0 & 82.5 & 78.8 \\
\hline Propamocarb & 82.5 & 72.5 & 72.5 & 65.0 & 77.5 & 62.5 & 82.5 & 75.0 & 73.8 \\
\hline Ipconazole + metalaxyl & 85.0 & 80.0 & 82.5 & 90.0 & 70.0 & 87.5 & 75.0 & 85.0 & 81.9 \\
\hline Iprodione & 90.0 & 90.0 & 67.5 & 75.0 & 90.0 & 95.0 & 80.0 & 82.5 & 83.8 \\
\hline $\begin{array}{l}\text { Sedaxane }+ \text { difenoconazole }+ \\
\text { metalaxyl }\end{array}$ & 80.0 & 70.0 & 72.5 & 85.0 & 85.0 & 92.5 & 77.5 & 82.5 & 80.6 \\
\hline Thiram & 95.0 & 82.5 & 72.5 & 55.0 & 82.5 & 67.5 & 80.0 & 90.0 & 78.1 \\
\hline \multirow[t]{2}{*}{ Mean } & 85.8 & 82.3 & 73.8 & 75.5 & 85.8 & 81.0 & 79.3 & 82.0 & 80.7 \\
\hline & \multicolumn{9}{|c|}{ Tap root disease index } \\
\hline Nil & 14.96 & 35.08 & 29.25 & 49.0 & 6.25 & 41.58 & 22.5 & 53.5 & 31.52 \\
\hline Dividend & 23.79 & 43.58 & 10.0 & 34.38 & 10.0 & 36.63 & 17.92 & 39.17 & 26.93 \\
\hline Fluquinconazole & 21.75 & 27.12 & 26.67 & 37.04 & 8.5 & 38.88 & 3.17 & 50.0 & 26.64 \\
\hline Metalaxyl & 12.12 & 41.0 & 8.21 & 38.83 & 15.25 & 33.96 & 5.25 & 39.88 & 24.31 \\
\hline Phosphonic acid & 28 & 25.29 & 22.29 & 48.42 & 5.87 & 32.88 & 6.25 & 43.25 & 26.53 \\
\hline Propamocarb & 16.67 & 37.04 & 20.96 & 34.42 & 10.0 & 27.71 & 6.75 & 46.58 & 25.02 \\
\hline Ipconazole + metalaxyl & 18.83 & 23.08 & 21.33 & 39.12 & 9.17 & 17.12 & 16.54 & 52.83 & 24.75 \\
\hline Iprodione & 42.13 & 32.75 & 31.67 & 34.71 & 3.62 & 38.75 & 26.62 & 40.25 & 31.31 \\
\hline $\begin{array}{l}\text { Sedaxane }+ \text { difenoconazole }+ \\
\text { metalaxyl }\end{array}$ & 14.62 & 27.5 & 11.58 & 44.12 & 2.75 & 27.88 & 23 & 28.83 & 22.54 \\
\hline Thiram & 22.62 & 46.08 & 27.17 & 32.08 & 3.12 & 15 & 29.42 & 42.5 & 27.25 \\
\hline \multirow[t]{2}{*}{ Mean } & 21.55 & 33.85 & 20.91 & 39.21 & 7.45 & 31.04 & 15.74 & 43.68 & 26.68 \\
\hline & \multicolumn{9}{|c|}{ Lateral root disease index } \\
\hline Nil & 24.33 & 56.46 & 37.25 & 71.08 & 3.13 & 30.54 & 26.04 & 44.21 & 36.63 \\
\hline Dividend & 30.54 & 58.92 & 17.63 & 56.75 & 7.38 & 34.63 & 16.46 & 14.0 & 29.54 \\
\hline Fluquinconazole & 20.63 & 42.75 & 41.38 & 51.83 & 0 & 34.21 & 3.0 & 42.42 & 29.53 \\
\hline Metalaxyl & 11.88 & 47.13 & 8.88 & 63.67 & 0 & 21.46 & 1.25 & 60.67 & 26.87 \\
\hline Phosphonic acid & 44.67 & 44.54 & 28.96 & 57.63 & 0 & 30.63 & 3.96 & 60.88 & 33.91 \\
\hline Propamocarb & 31.79 & 46.67 & 24.67 & 56.75 & 0 & 23.75 & 15.13 & 47.38 & 30.77 \\
\hline Ipconazole + metalaxyl & 28.42 & 49.17 & 22.88 & 52 & 1.67 & 14.04 & 12.75 & 43.63 & 28.07 \\
\hline Iprodione & 46.00 & 46.13 & 32.04 & 59.58 & 2.50 & 33.25 & 24.0 & 59.42 & 37.87 \\
\hline $\begin{array}{l}\text { Sedaxane }+ \text { difenoconazole }+ \\
\text { metalaxyl }\end{array}$ & 29.00 & 55.21 & 21.88 & 50.63 & 3.0 & 25.75 & 19.75 & 57.25 & 32.81 \\
\hline Thiram & 32.12 & 64.29 & 12.17 & 56.25 & 0 & 14.0 & 23.13 & 30.71 & 29.08 \\
\hline Mean & 29.94 & 51.13 & 24.77 & 57.62 & 1.77 & 26.23 & 14.55 & 46.06 & 31.51 \\
\hline & & & & Shoo & Iry weig & (mg) & & & \\
\hline Nil & 45.88 & 46.27 & 28.9 & 30.81 & 34.83 & 38.55 & 47.22 & 42.57 & 39.38 \\
\hline Dividend & 45.7 & 42.64 & 33.59 & 28.56 & 38.22 & 32.99 & 37.65 & 39.6 & 37.37 \\
\hline Fluquinconazole & 38.27 & 42.33 & 39.13 & 40.05 & 29.32 & 26.62 & 38.6 & 40.72 & 36.88 \\
\hline Metalaxyl & 38.35 & 38.14 & 39.26 & 45.49 & 26.11 & 29.2 & 47.64 & 41.1 & 38.16 \\
\hline Phosphonic acid & 41.53 & 40.39 & 46.00 & 33.89 & 30.97 & 32.54 & 40.07 & 42.42 & 38.48 \\
\hline Propamocarb & 36.7 & 44.39 & 48.36 & 40.68 & 33.11 & 28.1 & 43.28 & 41.41 & 39.50 \\
\hline Ipconazole + metalaxyl & 39.73 & 47.11 & 35.33 & 28.85 & 35.32 & 31.14 & 43.75 & 35.61 & 37.11 \\
\hline Iprodione & 42.45 & 51.04 & 44.26 & 41.73 & 34.26 & 30.54 & 50.21 & 46.51 & 42.63 \\
\hline $\begin{array}{l}\text { Sedaxane }+ \text { difenoconazole }+ \\
\text { metalaxyl }\end{array}$ & 43.17 & 48.33 & 32.38 & 36.47 & 34.47 & 31.57 & 48.3 & 43.95 & 39.83 \\
\hline Thiram & 47.00 & 46.4 & 41.6 & 51.35 & 35.04 & 34.08 & 46.31 & 34.69 & 42.06 \\
\hline Mean & 44.70 & 37.79 & 31.53 & 40.86 & 41.88 & 38.88 & 33.17 & 44.30 & 39.14 \\
\hline
\end{tabular}


Controlled environment Experiment 6: foliar fungicides against $\boldsymbol{P}$. clandestina. There were no significant effects of fungicide spray treatments on any of the assessment parameters except for reduced lateral root disease for Meteora when phosphonic acid had been sprayed (Table 11, Fig. 3).

Controlled environment Experiment 7: seed fungicides against $\boldsymbol{R}$. solani. There were no significant fungicide treatment effects for this experiment (data not shown). It was not considered worthwhile to subsequently test foliar fungicides against this pathogen as disease progression was particularly rapid and pre-empted application timing for foliar sprays.

Field studies 2015. There was extensive tap and lateral root disease in pre-existing subterranean clover forages at all eight field test sites. In particular, five sites showed very severe tap root disease (TDI\% range 70-80), six showed very severe lateral root disease (LDI\% range 57-80), and Rhizobium nodulation was very poor across seven sites (NI\% range 0-30). All test sites were confirmed to have a soilborne pathogen complex, with two sites having four pathogen groups, five sites having three pathogen groups, only one site having two pathogen groups. All but one site had a mixture of at least one major oomycete and one major fungal pathogen group (Table 2).

There were very few significant effects from either seed or foliar spray fungicide treatments in 2015 and data for sites/sampling times where there were no significant effects is not provided. In South Australia field site \#2 and in New South Wales field site \#1, both at first sampling, there was an effect of metalaxyl fungicide seed treatment on significantly improving germination, and at the New South Wales site, there was also significant improvement in germination from ipconazole + metalaxyl (Fig. 4A and B). In New South Wales field site \#2 at second sampling, there was a significant effect of both metalaxyl and phosphonic foliar sprays on reducing lateral root disease severity (Fig. 5A).

Field studies 2016. In 2016, as in 2015, there were again very few significant effects of either seed or foliar spray fungicide treatments and data for sites/sampling times where there were no significant effects is not provided. The only significant effects were in Western Australia field site \#2 at second sampling, where there was a significant effect of both phosphonic acid and metalaxyl foliar sprays on reducing lateral root disease severity (Fig. 5B), and for field site \#1 at second sampling, there was a significant effect of mixed fungicide seed treatment on increasing root and shoot dry weight per plant (Fig. 6B). In South Australia field site \#2 at first sampling, there was a significant effect of mixed fungicide seed treatment on increasing percent germination and percent nodulation index (Fig. 6A).

\section{Discussion}

Annual forage legumes across southern Australia continue to be devastated by soilborne diseases. This is the first comprehensive study to evaluate a wide range of different seed and foliar fungicide treatments across different clover cultivars against the most important individual oomycete soilborne pathogens $P$. irregulare, A. trifolii, and $P$. clandestina and the most important fungal pathogen, $R$. solani. Initially, studies were undertaken under controlled conditions and, subsequently, the efficacies of the most promising options were tested and compared in 2 years of field experiments across southern Australia. Overall, controlled environment studies highlighted strong potential for utilizing seed treatments against individual pathogens to ensure seedling emergence and early survival. For these controlled environment studies, seed and foliar sprays in many situations enhanced productivity by reducing seedling damping-off and root disease caused by individual pathogens. However, in field experiments over 2 years across southern Australia against naturally occurring soilborne pathogen complexes involving these same pathogens, fungicides tested rarely showed any benefit. It is evident that currently available fungicide seed and/or foliar spray treatment options do not offer effective field mitigation of damping-off and root disease on annual forage legumes that underpin livestock feed production across southern Australia.

In controlled environment experiments involving seed fungicides, against $P$. irregulare, across the four cultivars, thiram and metalaxyl were best against damping-off and for maximizing root and shoot weights, respectively. Greenhalgh (1983) also showed that metalaxyl at rates of $0.175-0.7 \%$ a.i. (wt/wt) of seed gave good control of root disease caused by $P$. irregulare under controlled environmental conditions. Against $P$. irregulare, it is evident that seed treatment is a promising route for ensuring seedling germination, establishment, survival, and productivity in situations where this pathogen is the only or predominate pathogen. Against $A$. trifolii, metalaxyl, iprodione, difenoconazole + metalaxyl, ipconazole + metalaxyl, and sedaxane + difenoconazole + metalaxyl, all reduced damping-off; sedaxane + difenoconazole + metalaxyl, fluquinconazole, and ipconazole + metalaxyl all reduced lateral root disease across two or more cultivars. Iprodione, thiram, and sedaxane + difenoconazole + metalaxyl increased shoot dry weight. Against $P$. clandestina, metalaxyl was the most effective against tap and lateral root rot followed by ipconazole + metalaxyl or phosphonic acid for tap and lateral rot, respectively. Against $R$. solani, there were no effects of fungicides. In contrast, Almasudy et al. (2015) showed that, under artificial conditions, ipconazole + metalaxyl was highly effective in reducing root disease from $R$. solani anastomosis group (AG) 8 in wheat, but that difenoconazole was largely ineffective. Under controlled environment and/or single pathogen situations, overall, there is strong potential for utilizing seed treatments against individual pathogens to ensure seedling emergence and early survival. In such situations, increased productivity can be expected from reduced seedling root disease caused by some of the tested individual pathogens.

In controlled environment experiments involving foliar sprays, overall, phosphonic acid was best at preventing productivity losses from A. trifolii, but was overall ineffective against $P$. clandestina, $P$. irregulare, and $R$. solani in terms of controlling damping-off and root disease. This is in contrast to earlier studies of Hochman et al. (1990) and Burnett et al. (1994), who showed that metalaxyl could provide useful field control of root disease, especially when caused by $P$. clandestina. Greenhalgh et al. (1994) and Greenhalgh and Clarke (1985) showed similar outcomes for applications of potassium phosphonate, primarily against this same pathogen. Under

Table 7. Controlled Experiment 4: Foliar treatments against Aphanomyces trifolii. Statistical main effects and interactions ( $P$ and LSD values)

\begin{tabular}{|c|c|c|c|c|c|c|c|c|c|c|}
\hline \multirow[b]{2}{*}{ Main effects } & \multicolumn{2}{|c|}{ Emergence \% } & \multicolumn{2}{|c|}{$\begin{array}{l}\text { Tap root disease } \\
\text { index }\end{array}$} & \multicolumn{2}{|c|}{$\begin{array}{l}\text { Lateral root disease } \\
\text { index }\end{array}$} & \multicolumn{2}{|c|}{$\begin{array}{l}\text { Shoot dry weight } \\
(\mathbf{m g})\end{array}$} & \multicolumn{2}{|c|}{$\begin{array}{l}\text { Root dry weight } \\
(\mathrm{mg})\end{array}$} \\
\hline & $\begin{array}{c}P \\
\text { value }\end{array}$ & LSD $=0.05$ & $\begin{array}{c}P \\
\text { value }\end{array}$ & LSD $=0.05$ & $\begin{array}{c}P \\
\text { value }\end{array}$ & LSD $=0.05$ & $\begin{array}{c}P \\
\text { value }\end{array}$ & LSD $=0.05$ & $\begin{array}{c}P \\
\text { value }\end{array}$ & LSD $=0.05$ \\
\hline Fungicide spray treatment & NS & - & 0.043 & 12.56 & 0.004 & 12.33 & $<0.001$ & 3.923 & $<0.001$ & 2.295 \\
\hline Cultivars & 0.003 & 8.76 & 0.013 & 11.24 & $<0.001$ & 11.02 & $<0.001$ & 3.509 & $<0.001$ & 2.053 \\
\hline Fungicide spray treatment $\times$ inoculation & NS & - & NS & - & NS & - & NS & - & NS & - \\
\hline Fungicide spray treatment $\times$ cultivars & NS & - & NS & - & NS & - & NS & - & NS & - \\
\hline Inoculation $\times$ cultivars & NS & - & NS & - & NS & - & NS & - & 0.047 & 2.903 \\
\hline $\begin{array}{l}\text { Fungicide spray treatment } \times \text { inoculation } \times \\
\text { cultivars }\end{array}$ & NS & - & NS & - & NS & - & NS & - & NS & - \\
\hline
\end{tabular}


controlled environment and/or possibly in single-pathogen field situations, there is potential for utilizing foliar sprays to enhance productivity from reducing seedling root disease.

In contrast to the outcomes from controlled environment experiments involving individual pathogens, in Australia-wide national field experiments 2015 and 2016, against naturally occurring soilborne pathogen complexes involving these same pathogens, fungicides tested showed little or no benefit. This was the outcome even when combinations of fungicides were applied. Perhaps this should have been expected, as across these national field trial sites used, it was found that $P$. clandestina, $P$. irregulare, A. trifolii, and $R$. solani generally occur as complexes of 2-4 different pathogens (Foster et al. 2017) and as we specifically confirmed in the current study. In terms of overall losses, other studies showed that soilborne pathogens reduced field germination, root and shoot systems up to 70, 90, and $85 \%$, respectively, and were the overriding reason why subterranean clover does not persist in severely affected legume forages (Barbetti et al.1986a, 2006a, 2007; Wong et al. 1984; M. P. You and M. J. Barbetti, unpublished). Individually, in the field, $P$. irregulare reduced germination by up to $60 \%$ and with up to a $50 \%$ loss in plant productivity; $P$. clandestina reduced germination by up to $25 \%$ and caused a $4.5-$ fold loss in plant productivity; $R$. solani reduced germination by up to $90 \%$ and caused up to 75 to $80 \%$ loss in shoot and root production; $A$. trifolii reduced germination by up to $14 \%$ and caused up to 50 to $55 \%$ loss in shoot and root systems (M. P. You and M. J. Barbetti, unpublished). However, when there were two or more pathogens, up to $100 \%$ germination failure and total loss of root and shoot production occurred (M. P. You and M. J. Barbetti, unpublished). The need for effective, reliable, practical, and flexible fungicide options to reduce the losses during autumn-winter period from soilborne dampingoff and root disease in critical. Yet the performance of fungicide seed treatments in current field studies showed very low efficacy. This was so even in comparison with some historical field experiments where a range of different fungicide seed treatments were tested under field conditions across two growing seasons (1984 and 1985) in Western Australia for their efficacy in controlling root disease of subterranean clover (Barbetti et al. 1987b). In those earlier studies, some seed treatments resulted in large increases in seedling survival and decreases in tap and lateral root disease severity, particularly treatments containing metalaxyl, perhaps the fungicide most expected to be effective as it is strongly selective against oomycetes (Schwinn et al. 1977). In these same historical experiments, even thiram and propamocarb showed some effectiveness, but benomyl and iprodione were ineffective. However, there was likely more potential for fungicides to be effective in the 1980s for two reasons. First, there was only a single known race of $P$. clandestina in Western Australia at that time (Taylor et al. 1985a), compared with 31 currently (Foster et al. 2017). Also, A. trifolii was not known to be present at that time (Ma et al. 2008; O'Rourke et al. 2010). Similar to current field studies, Barbetti et al. (1987b) found in-field response to seed treatments variable between both sites and seasons. Despite observing some large increases in seedling survival and decreases in tap and lateral root rot levels with some in-field seed treatments, Barbetti et al. (1987b) hesitated to make any recommendations for using fungicidal seed treatments at that time. Not only did they find that response to seed treatments was variable both between sites and from season to

Table 8. Controlled Experiment 4: Foliar treatments against Aphanomyces trifolii. Effect of fungicide spray treatments on emergence (\%), tap and lateral root rot disease indices, shoot and root dry weights $(\mathrm{mg})$. Means are shown in italics.

\begin{tabular}{|c|c|c|c|c|c|c|c|c|c|}
\hline \multirow{2}{*}{$\frac{\text { Cultivars }}{\text { Inoculum }}$} & \multicolumn{2}{|c|}{ Meteora } & \multicolumn{2}{|c|}{ Riverina } & \multicolumn{2}{|c|}{ Seaton Park } & \multicolumn{2}{|c|}{ Woogenellup } & \multirow[b]{2}{*}{ Mean } \\
\hline & Nil & A. trifolii & Nil & A. trifolii & Nil & A. trifolii & Nil & A. trifolii & \\
\hline & \multicolumn{9}{|c|}{ Emergence rate (\%) } \\
\hline Nil & 85.0 & 70.0 & 75.0 & 72.5 & 82.5 & 77.5 & 80.0 & 77.5 & 78.6 \\
\hline Metalaxyl & 82.5 & 87.5 & 85.0 & 72.5 & 80.0 & 80.0 & 70.0 & 80.0 & 78.6 \\
\hline Phosphonic acid & 80.0 & 82.5 & 85.0 & 67.5 & 100 & 90.0 & 80.0 & 90.0 & 84.6 \\
\hline Propamocarb & 87.5 & 80 & 70.0 & 67.5 & 92.5 & 95.0 & 87.5 & 85.0 & 83.6 \\
\hline Iprodione & 82.5 & 87.5 & 85.0 & 72.5 & 80.0 & 80.0 & 70 & 80.0 & 78.6 \\
\hline \multirow[t]{2}{*}{ Mean } & 83.5 & 81.5 & 77.0 & 70.5 & 91.0 & 86.5 & 76 & 82.5 & 81.0 \\
\hline & \multicolumn{9}{|c|}{ Tap root disease index } \\
\hline Nil & 0 & 23.3 & 0 & 45.6 & 0 & 44.1 & 0 & 54.1 & 41.8 \\
\hline Metalaxyl & 0 & 31.5 & 0 & 40.0 & 0 & 20.5 & 0 & 39.5 & 32.9 \\
\hline Phosphonic acid & 0 & 8.3 & 0 & 15.0 & 0 & 34.8 & 0 & 28.9 & 21.8 \\
\hline Propamocarb & 0 & 30.6 & 0 & 39.7 & 0 & 15.5 & 0 & 34.8 & 30.2 \\
\hline Iprodione & 0 & 20.4 & 0 & 36.0 & 0 & 24.3 & 0 & 43.7 & 31.1 \\
\hline \multirow[t]{2}{*}{ Mean } & 0 & 22.8 & 0 & 35.3 & 0 & 27.8 & 0 & 40.2 & 31.5 \\
\hline & \multicolumn{9}{|c|}{ Lateral root disease index } \\
\hline Nil & 0 & 40.9 & 0 & 54.1 & 0 & 32.9 & 0 & 64.1 & 48.0 \\
\hline Metalaxyl & 0 & 41.2 & 0 & 54.4 & 0 & 18.8 & 0 & 32.7 & 36.8 \\
\hline Phosphonic acid & 0 & 20.1 & 0 & 30.1 & 0 & 23.4 & 0 & 23.6 & 24.3 \\
\hline Propamocarb & 0 & 47.2 & 0 & 51.2 & 0 & 16.0 & 0 & 30.9 & 36.3 \\
\hline Iprodione & 0 & 50.5 & 0 & 64.0 & 0 & 21.2 & 0 & 34.0 & 42.4 \\
\hline \multirow[t]{2}{*}{ Mean } & 0 & 40.0 & 0 & 50.8 & 0 & 22.5 & 0 & 37.1 & 37.6 \\
\hline & \multicolumn{9}{|c|}{ Shoot dry weight $(\mathrm{mg})$} \\
\hline Nil & 22.8 & 25.4 & 16.3 & 26.9 & 17.7 & 18.6 & 21.3 & 23.8 & 21.6 \\
\hline Metalaxyl & 40.1 & 40.5 & 38.3 & 41.3 & 35.7 & 31.4 & 44.7 & 41.6 & 39.2 \\
\hline Phosphonic acid & 40.4 & 47.1 & 34.2 & 39.0 & 38.0 & 24.0 & 44.5 & 38.5 & 38.2 \\
\hline Propamocarb & 39.9 & 43.7 & 37.8 & 37.9 & 33.5 & 29.1 & 40.9 & 34.2 & 37.1 \\
\hline Iprodione & 47.1 & 45.4 & 42.9 & 32.1 & 37.7 & 34.9 & 52.5 & 42.4 & 41.9 \\
\hline \multirow[t]{2}{*}{ Mean } & 38.1 & 40.4 & 33.9 & 35.4 & 32.5 & 27.6 & 40.8 & 36.1 & 35.6 \\
\hline & \multicolumn{9}{|c|}{ Root dry weight (mg) } \\
\hline Nil & 18.7 & 21.0 & 17.3 & 17.9 & 17.6 & 14.7 & 21.3 & 22.7 & 18.9 \\
\hline Metalaxyl & 8.4 & 12.7 & 7.4 & 13.1 & 9.5 & 9.8 & 12.1 & 13.4 & 10.8 \\
\hline Phosphonic acid & 17.2 & 23.6 & 16.0 & 20.1 & 17.1 & 13.6 & 21.1 & 17.7 & 18.3 \\
\hline Propamocarb & 17.1 & 19.0 & 14.6 & 21.5 & 15.1 & 13.3 & 17.9 & 16.0 & 16.8 \\
\hline Iprodione & 19.6 & 17.8 & 19.8 & 17.8 & 14.6 & 16.7 & 22.6 & 17.7 & 18.3 \\
\hline Mean & 16.2 & 18.8 & 15.0 & 18.1 & 14.8 & 13.6 & 19.0 & 17.5 & 16.6 \\
\hline
\end{tabular}


season, but the same applied in earlier field studies (e.g., Barbetti 1983, 1984a, b, 1985).

While not part of the current study, fungicide drenches as used in some historical studies also help explain the ineffectiveness of fungicides in the current field studies. For example, Barbetti et al. (1987a), using a range of different fungicide drenches, found metalaxyl best for increasing subterranean clover seedling survival, followed by thiram, but with little effect of propamocarb and no effect of iprodione.
The variable and often poor disease control outcomes from those field trials again highlighted that different pathogens and/or pathogen complexes were involved in the different locations and across different seasons. Even more concerning were instances where different pathogen complexes were responsible for the rotting of the tap-root system compared with the lateral root system (e.g., Barbetti et al. 1987a), further challenging the value of using fungicides to mitigate damage from pathogen complexes. That the effectiveness of any

Table 9. Controlled Experiment 5: Seed treatments against Phytophthora clandestina. Statistical main effects and their interactions on tap and root disease index (TDI\% and LDI\%), nodulation index (NI\%), and dry root weight and dry shoot weight per plant (DRW (mg/p) and DSW (mg/p)).

\begin{tabular}{|c|c|c|c|c|c|c|c|c|c|c|}
\hline \multirow[b]{2}{*}{ Main factor } & \multicolumn{2}{|c|}{ TDI\% } & \multicolumn{2}{|c|}{ LDI\% } & \multicolumn{2}{|c|}{ NI\% } & \multicolumn{2}{|c|}{ DRW (mg/p) } & \multicolumn{2}{|c|}{ DSW (mg/p) } \\
\hline & $P_{0.05}$ & LSD $_{0.05}$ & $P_{0.05}$ & LSD $_{0.05}$ & $P_{0.05}$ & LSD $_{0.05}$ & $P_{0.05}$ & LSD $_{0.05}$ & $P_{0.05}$ & LSD $_{0.05}$ \\
\hline Fungicide & $<0.001$ & 2.356 & $<0.001$ & 2.564 & 0.187 & 0.3783 & 0.459 & 34.6 & 0.416 & 6.725 \\
\hline Pathogen & $<0.001$ & 1.054 & $<0.001$ & 1.147 & 0.003 & 0.1692 & 0.82 & 15.48 & $<0.001$ & 3.007 \\
\hline Cultivar & $<0.001$ & 1.49 & $<0.001$ & 1.622 & 0.343 & 0.2393 & 0.172 & 21.89 & $<0.001$ & 4.253 \\
\hline Interactions & & & & & & & & & & \\
\hline Fungicide $\times$ pathogen & 0.001 & 3.332 & $<0.001$ & 3.626 & 0.19 & 0.535 & 0.482 & 48.94 & 0.619 & 9.51 \\
\hline Fungicide $\times$ cultivar & 0.002 & 4.712 & $<0.001$ & 5.128 & 0.12 & 0.7566 & 0.422 & 69.21 & 0.336 & 13.45 \\
\hline Pathogen $\times$ cultivar & $<0.001$ & 2.107 & $<0.001$ & 2.294 & 0.343 & 0.3384 & 0.156 & 30.95 & $<0.001$ & 6.015 \\
\hline Fungicide $\times$ pathogen $\times$ cultivar & 0.003 & 6.664 & $<0.001$ & 7.253 & 0.12 & 1.07 & 0.338 & 97.87 & 0.174 & 19.021 \\
\hline
\end{tabular}

Table 10. Controlled Experiment 5: Seed treatments against Phytophthora clandestina. Effect of fungicides on tap and root disease index (TDI\% and LDI\%), nodulation index (NI\%), and dry root weight and dry shoot weight per plant (DRW (mg/p) and DSW (mg/p)).

\begin{tabular}{|c|c|c|c|c|c|c|c|c|c|c|c|}
\hline \multirow[b]{2}{*}{ Fungicide } & \multirow[b]{2}{*}{ Cultivar } & \multicolumn{2}{|c|}{ TDI\% } & \multicolumn{2}{|c|}{ LDI\% } & \multicolumn{2}{|c|}{ DRW (mg/p) } & \multirow{2}{*}{$\frac{\text { DRW (mg/p) }}{\text { Deduction\% }}$} & \multicolumn{2}{|c|}{ DSW (mg/p) } & \multirow{2}{*}{$\frac{\text { DSW }(\mathrm{mg} / \mathrm{p})}{\text { Deduction } \%}$} \\
\hline & & Nil & Phyto & Nil & Phyto & Nil & Phyto & & Nil & P. cl & \\
\hline \multirow[t]{4}{*}{$\overline{\text { Dividend }}$} & Meteora & 0.00 & 19.00 & 0.00 & 17.67 & 30.60 & 23.30 & 23.86 & 71.96 & 55.10 & 23.43 \\
\hline & Riverina & 0.00 & 27.00 & 0.00 & 28.58 & 37.80 & 15.20 & 59.79 & 77.18 & 39.05 & 49.40 \\
\hline & Seaton Park & 0.00 & 0.50 & 0.00 & 0.00 & 22.60 & 25.50 & 0.00 & 52.26 & 45.19 & 13.53 \\
\hline & Woogenellup & 0.00 & 64.67 & 0.00 & 73.37 & 18.30 & 9.20 & 49.73 & 54.58 & 15.33 & 71.91 \\
\hline \multirow[t]{4}{*}{ Fluquinconazole } & Meteora & 0.00 & 22.83 & 0.00 & 25.58 & 26.20 & 20.40 & 22.14 & 70.64 & 45.37 & 35.77 \\
\hline & Riverina & 0.00 & 35.25 & 0.00 & 30.08 & 38.10 & 15.40 & 59.58 & 76.66 & 39.11 & 48.98 \\
\hline & Seaton Park & 0.00 & 2.25 & 0.00 & 0.00 & 26.20 & 27.60 & 0.00 & 58.73 & 56.57 & 3.68 \\
\hline & Woogenellup & 0.00 & 60.25 & 0.00 & 71.13 & 21.20 & 3.80 & 82.08 & 59.71 & 13.30 & 77.73 \\
\hline \multirow[t]{4}{*}{ Metalaxyl } & Meteora & 0.00 & 15.92 & 0.00 & 11.30 & 28.70 & 18.20 & 36.59 & 70.27 & 46.16 & 34.31 \\
\hline & Riverina & 0.00 & 15.17 & 0.00 & 14.75 & 37.30 & 18.30 & 50.94 & 80.35 & 46.17 & 42.54 \\
\hline & Seaton Park & 0.00 & 6.83 & 0.00 & 1.88 & 22.70 & 21.60 & 4.85 & 54.26 & 42.08 & 22.45 \\
\hline & Woogenellup & 0.00 & 53.33 & 0.00 & 32.62 & 19.80 & 23.00 & 0.00 & 55.74 & 44.81 & 19.61 \\
\hline \multirow[t]{4}{*}{ Nil } & Meteora & 0.00 & 27.50 & 0.00 & 22.88 & 29.00 & 28.80 & 0.69 & 80.80 & 62.50 & 22.65 \\
\hline & Riverina & 0.00 & 27.13 & 0.00 & 35.25 & 34.10 & 17.50 & 48.68 & 73.20 & 45.56 & 37.76 \\
\hline & Seaton Park & 0.00 & 1.67 & 0.00 & 2.50 & 31.40 & 22.80 & 27.39 & 62.68 & 48.29 & 22.96 \\
\hline & Woogenellup & 0.00 & 64.79 & 0.00 & 71.67 & 22.70 & 8.20 & 63.88 & 63.32 & 24.26 & 61.69 \\
\hline \multirow[t]{4}{*}{ Phosphonic acid } & Meteora & 0.00 & 13.96 & 0.00 & 13.96 & 30.80 & 28.90 & 6.17 & 74.03 & 60.73 & 17.97 \\
\hline & Riverina & 0.00 & 26.58 & 0.00 & 26.50 & 32.60 & 20.40 & 37.42 & 75.81 & 41.37 & 45.43 \\
\hline & Seaton Park & 0.00 & 1.50 & 0.00 & 0.00 & 29.50 & 17.40 & 41.02 & 57.76 & 36.53 & 36.76 \\
\hline & Woogenellup & 0.00 & 66.46 & 0.00 & 59.92 & 29.40 & 9.20 & 68.71 & 70.09 & 24.63 & 64.86 \\
\hline \multirow[t]{4}{*}{ Propamocarb } & Meteora & 2.50 & 26.25 & 0.00 & 25.21 & 40.30 & 16.40 & 59.31 & 73.53 & 43.77 & 40.47 \\
\hline & Riverina & 0.00 & 26.67 & 0.00 & 33.12 & 20.10 & 18.00 & 10.45 & 62.49 & 45.32 & 27.48 \\
\hline & Seaton Park & 0.00 & 4.29 & 0.00 & 2.12 & 23.70 & 341.30 & 0.00 & 46.84 & 50.29 & 0.00 \\
\hline & Woogenellup & 0.00 & 62.50 & 0.00 & 73.67 & 29.20 & 3.40 & 88.36 & 75.87 & 17.84 & 76.49 \\
\hline \multirow[t]{4}{*}{ Rancona Dimension } & Meteora & 0.00 & 20.88 & 0.00 & 18.96 & 37.00 & 22.60 & 38.92 & 90.52 & 54.05 & 40.29 \\
\hline & Riverina & 0.00 & 17.25 & 0.00 & 24.00 & 24.70 & 25.40 & 0.00 & 70.35 & 58.28 & 17.16 \\
\hline & Seaton Park & 0.00 & 1.50 & 0.00 & 0.00 & 24.60 & 22.90 & 6.91 & 55.41 & 41.36 & 25.36 \\
\hline & Woogenellup & 0.00 & 59.46 & 0.00 & 65.50 & 21.90 & 5.10 & 76.71 & 63.27 & 19.51 & 69.16 \\
\hline \multirow[t]{4}{*}{ Iprodione } & Meteora & 0.00 & 27.33 & 0.00 & 29.46 & 23.20 & 23.60 & 0.00 & 71.40 & 53.89 & 24.52 \\
\hline & Riverina & 0.00 & 22.88 & 0.00 & 26.92 & 22.00 & 26.50 & 0.00 & 59.10 & 58.88 & 0.37 \\
\hline & Seaton Park & 0.00 & 3.13 & 0.00 & 4.62 & 21.00 & 22.00 & 0.00 & 54.30 & 43.86 & 19.23 \\
\hline & Woogenellup & 0.00 & 68.29 & 0.00 & 76.38 & 18.00 & 9.40 & 47.78 & 60.62 & 21.15 & 65.11 \\
\hline \multirow[t]{4}{*}{ Syn-A16874F } & Meteora & 0.00 & 28.63 & 0.00 & 40.38 & 27.40 & 18.20 & 33.58 & 71.10 & 40.27 & 43.36 \\
\hline & Riverina & 0.00 & 26.83 & 0.00 & 36.54 & 35.50 & 12.80 & 63.94 & 77.27 & 39.66 & 48.67 \\
\hline & Seaton Park & 0.00 & 6.63 & 0.00 & 0.00 & 27.50 & 21.70 & 21.09 & 55.14 & 41.96 & 23.90 \\
\hline & Woogenellup & 0.00 & 58.25 & 0.00 & 68.42 & 22.00 & 4.40 & 80.00 & 64.34 & 16.08 & 75.01 \\
\hline \multirow[t]{4}{*}{ Thiram } & Meteora & 0.00 & 31.33 & 0.00 & 31.88 & 27.40 & 13.50 & 50.73 & 68.62 & 43.94 & 35.97 \\
\hline & Riverina & 0.00 & 37.08 & 0.00 & 39.58 & 25.80 & 11.70 & 54.65 & 63.83 & 31.11 & 51.26 \\
\hline & Seaton Park & 0.00 & 1.88 & 0.00 & 0.00 & 30.70 & 29.20 & 4.89 & 58.87 & 57.02 & 3.14 \\
\hline & Woogenellup & 0.00 & 60.54 & 0.00 & 70.92 & 33.50 & 9.90 & 70.45 & 66.15 & 16.91 & 74.44 \\
\hline
\end{tabular}


particular fungicide(s) in the field is dependent upon geographic location and year/season (Barbetti et al. 1987a, b) as a consequence of changes within the soilborne pathogen complex in relation to the geographic and temporal situation (Barbetti et al. 1987a, b, 2007) presents a huge challenge to successful use of fungicide treatments.

Importantly, under controlled environment conditions for $P$. irregulare, A. trifolii, and P. clandestina in particular, there were strong fungicide $\times$ cultivar interactions highlighting the cultivar dependency of outcomes. Examples include the following: Against $P$. irregulare, seed treatment with iprodione gave high protection against damping-off for cultivars Meteora, Seaton Park, and Woogenellup but not Riverina. Sedaxane + difenoconazole + metalaxyl and ipconazole + metalaxyl gave good protection for cultivars Riverina, Seaton Park, and Woogenellup but not for Meteora. For the same pathogen but for fungicide spray treatments, Seaton Park was best and Woogenellup second best in terms of germination, Riverina and Woogenellup were better than Meteora and Seaton Park in terms of root dry weight, and Riverina best and Meteora second best in terms of nodulation. Against A. trifolii,

A
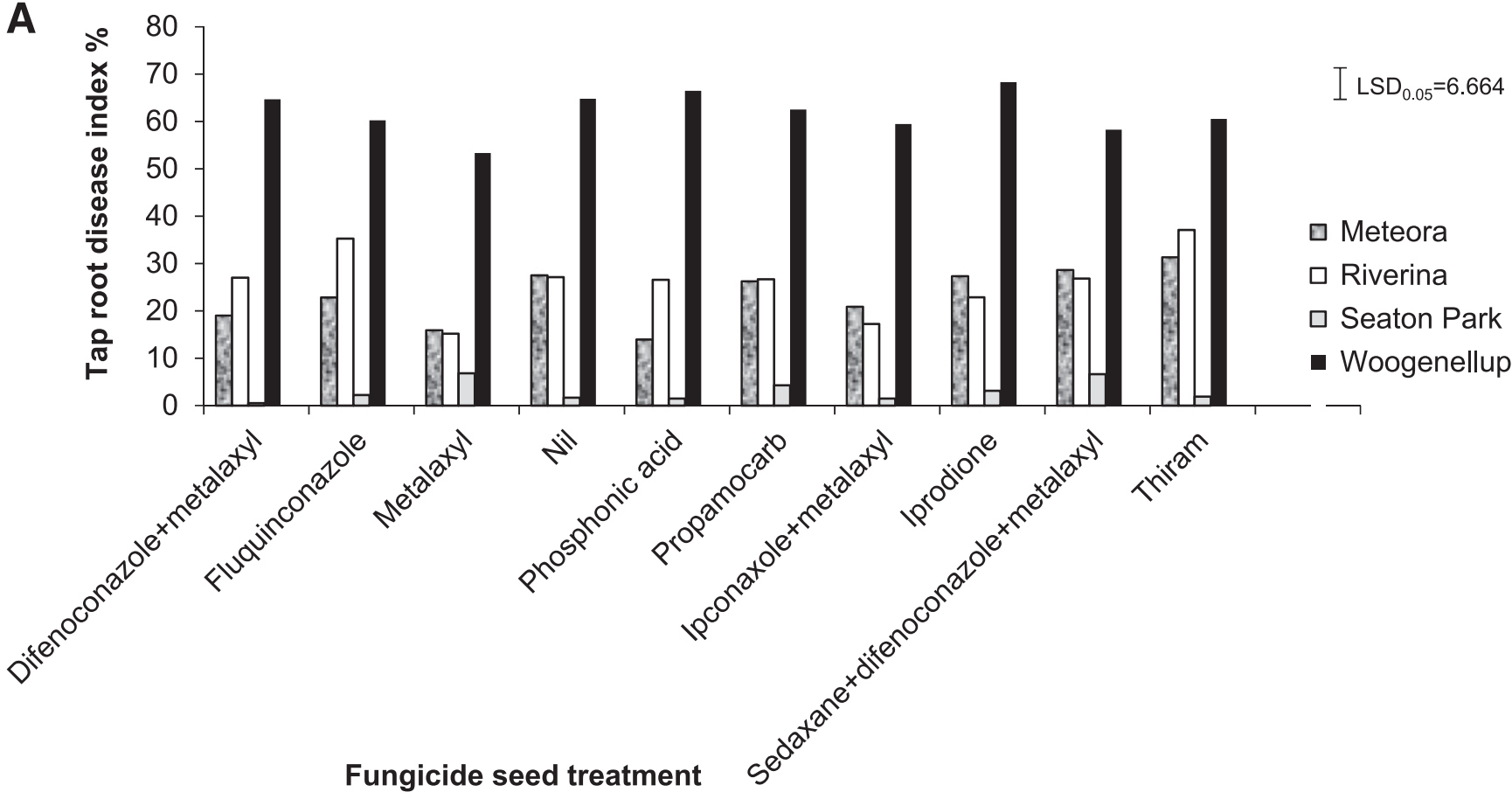

B
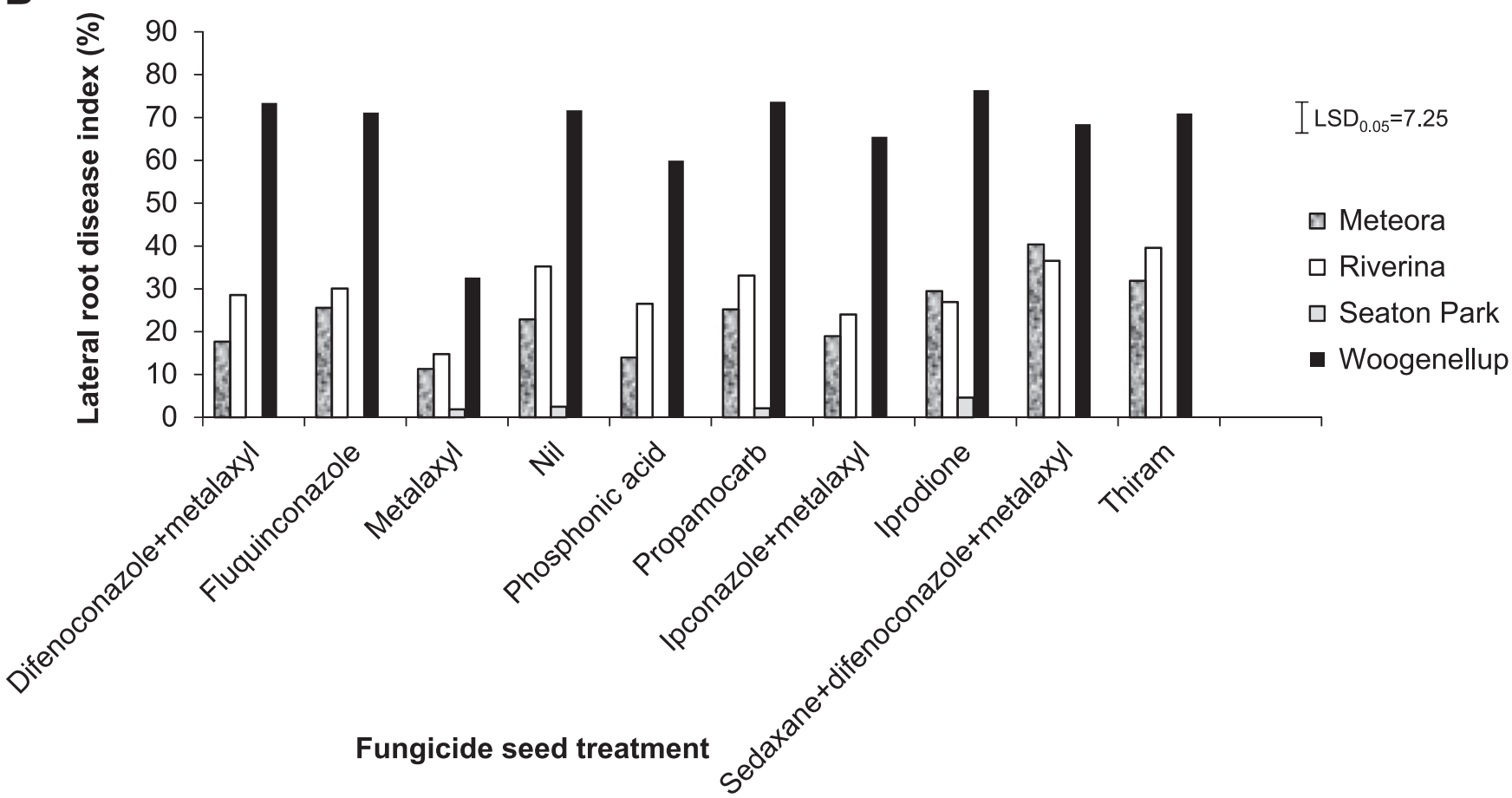

Fig. 2. Controlled environment studies: Effects of fungicide seed treatment on Phytophthora clandestina root disease index (\%) of cultivars Meteora, Riverina, Seaton Park, and Woogenellup; A, tap root disease; $\mathbf{B}$, lateral root disease index. 
seed treatments ipconazole + metalaxyl, difenoconazole + metalaxyl, and sedaxane + difenoconazole + metalaxyl gave high protection against damping-off for Riverina, sedaxane + difenoconazole + metalaxyl and difenoconazole + metalaxyl showed best protection for Seaton Park, while thiram and difenoconazole + metalaxyl showed good protection for Woogenellup. Yet, for this same pathogen in terms of root disease, cultivars Meteora and Riverina showed least lateral root rot when treated by fluquinconazole, but for Seaton Park and Woogenellup this occurred when treated by thiram or ipconazole + metalaxyl. Against $P$. clandestina, the interaction of seed fungicide with cultivar was well illustrated where phosphonic acid significantly reduced tap root disease on Meteora but not Riverina, while metalaxyl and ipconazole + metalaxyl reduced tap root disease on both Meteora and Riverina. For $P$. clandestina, least tap root disease occurred on Seaton Park, a variety that is highly resistant, and so there was overall no benefit from utilizing fungicides on this cultivar. In relation to lateral root disease, metalaxyl was again the best across Meteora, Riverina, and Woogenellup, followed by phosphonic acid across the same cultivars; then ipconazole + metalaxyl, but only for Riverina and Woogenellup. This is perhaps not surprising as these cultivars have differing resistance against both these pathogens (Nichols et al. 2014) and differential gene expression where root disease is driven by interactions with cultivar (You et al., unpublished). Hence, an important future focus will be to not only identify host resistances and tolerances against the soilborne pathogen complex, but to identify and combine host resistance and/or tolerance with particular fungicide seed options to maximize forage legume productivity.

It is evident that developing and deploying cultivars with increased field resistance to root rot is the best long-term means to manage these soilborne disease complexes. This is despite the high cost and challenges of renovating 'permanent' annual legume forages. As a basis to breed cultivars with resistance(s) to different soilborne pathogens, current resistances to individual soilborne pathogens can be utilized. Examples include: Karridale showing strong resistance, and even Dinninup, Enfield, Mt Barker, and Urana showing moderate resistance, against $P$. irregulare (Nichols et al. 2014). Seaton Park is known to have the greatest resistance to the majority of known races of $P$. clandestina (You et al. 2005b). Yarloop has best greatest resistance against $A$. trifolii (You et al. 2016), and Daliak, Dinninup, and Junee have greatest resistance against $R$. solani (Barbetti et al. 1986b). Additionally, some subterranean clover cultivars that exhibit strong field resistance to root rot, such as Junee and Karridale (Nicholas 1985a, b), have been recommended for sowing across regions covering some of the worst root rot-affected areas across southern Australia. Of particular interest are ongoing studies to identify field tolerance against the full range of pathogens involved in soilborne disease complexes,

Table 11. Controlled Experiment 6: Foliar treatments against Phytophthora clandestina. Statistical effect of main effects and their interactions on germination \%, tap and root disease index (TDI\% and LDI\%), nodulation index (NI\%), and dry root weight and dry shoot weight per plant (DRW (mg/p) and DSW (mg/p)).

\begin{tabular}{|c|c|c|c|c|c|c|c|c|c|c|c|c|}
\hline & \multicolumn{2}{|c|}{ TDI\% } & \multicolumn{2}{|c|}{ LDI\% } & \multicolumn{2}{|c|}{ NI\% } & \multicolumn{2}{|c|}{ Germination \% } & \multicolumn{2}{|c|}{ DRW (mg/P) } & \multicolumn{2}{|c|}{ DSW (mg/P) } \\
\hline & $P_{0.05}$ & LSD $_{0.05}$ & $P_{0.05}$ & LSD $_{0.05}$ & $P_{0.05}$ & LSD $_{0.05}$ & $P_{0.05}$ & LSD $_{0.05}$ & $P_{0.05}$ & LSD $_{0.05}$ & $P_{0.05}$ & LSD $_{0.05}$ \\
\hline \multicolumn{13}{|l|}{ Main factor } \\
\hline Fungicide & 0.883 & 2.154 & 0.028 & 1.856 & 0.082 & 2.776 & 0.922 & 6.8 & 0.303 & 6.25 & 0.326 & 12.71 \\
\hline Pathogen & $<0.001$ & 1.362 & $<0.001$ & 1.174 & 0.014 & 1.756 & 0.607 & 4.3 & $<0.001$ & 3.95 & $<0.001$ & 8.04 \\
\hline Cultivar & $<0.001$ & 1.926 & $<0.001$ & 1.66 & $<0.001$ & 2.483 & $<0.001$ & 6.08 & $<0.001$ & 5.59 & $<0.001$ & 11.37 \\
\hline \multicolumn{13}{|l|}{ Interaction } \\
\hline Fungicide $\times$ pathogen & 0.883 & 3.046 & 0.028 & 2.624 & 0.279 & 3.926 & 0.462 & 9.61 & 0.499 & 8.83 & 0.685 & 17.98 \\
\hline Fungicide $\times$ cultivar & 0.239 & 4.307 & $<0.001$ & 3.711 & 0.433 & 5.552 & 0.875 & 13.6 & 0.272 & 12.49 & 0.441 & 25.43 \\
\hline Pathogen $\times$ cultivar & $<0.001$ & 2.724 & $<0.001$ & 2.347 & $<0.001$ & 3.511 & 0.51 & 8.6 & $<0.001$ & 7.9 & $<0.001$ & 16.08 \\
\hline Fungicide $\times$ pathogen $\times$ cultivar & 0.239 & 6.091 & $<0.001$ & 5.249 & 0.373 & 7.852 & 0.674 & 19.23 & 0.092 & 17.67 & 0.681 & 35.96 \\
\hline
\end{tabular}

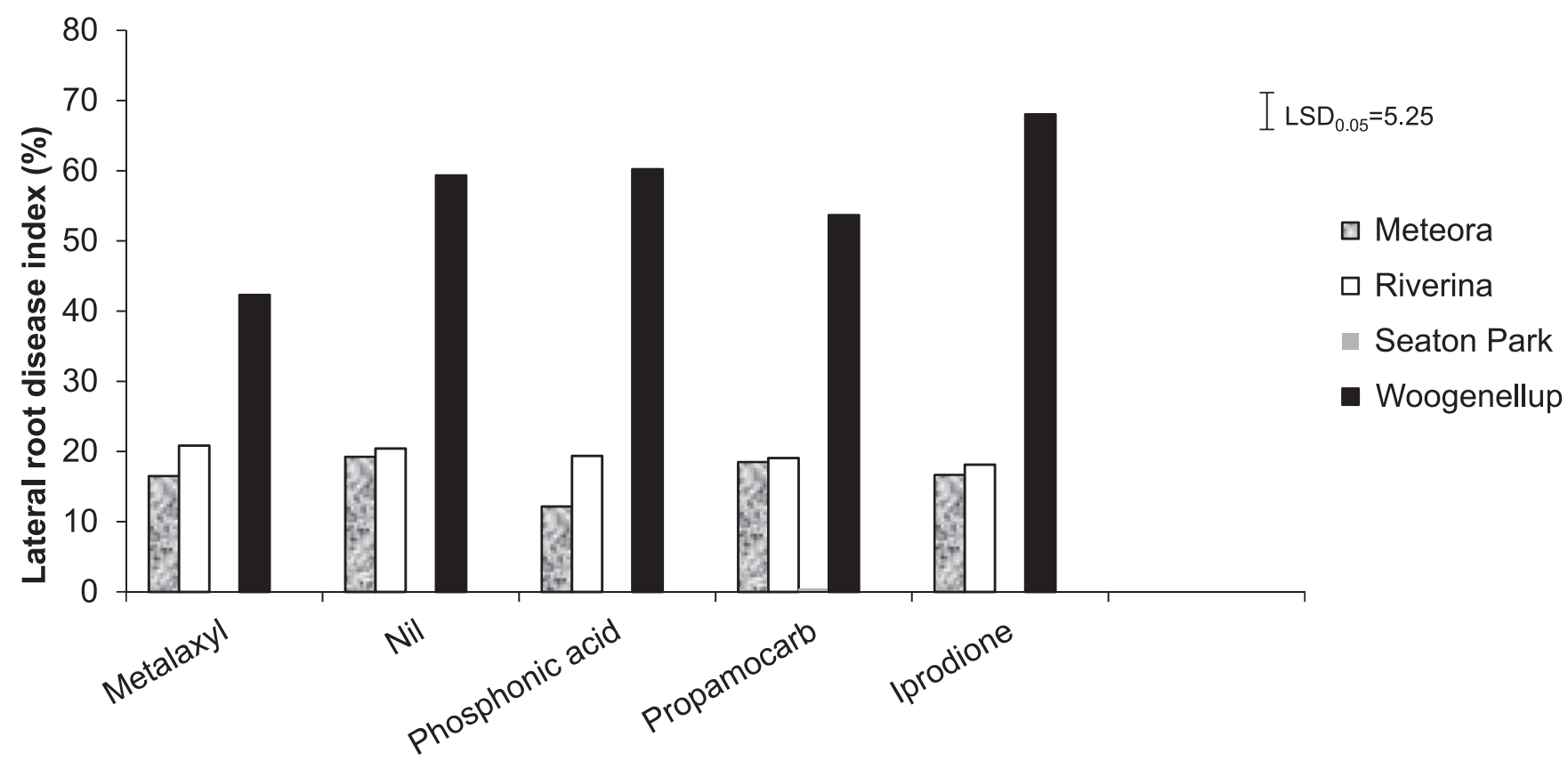

\section{Fungicide spray treatment}

Fig. 3. Controlled environment studies: Fungicide spray effect on Phytophthora clandestina lateral root disease index (\%) of cultivars Meteora, Riverina, Seaton Park, and Woogenellup. 
studies that have recently demonstrated both the feasibility and longterm advantages of such an approach (M. P. You and M. J. Barbetti, unpublished).

It clear that fungicide control options face significant challenges in field situations favorable to development of soilborne pathogen complexes, both as across the eight field sites used in the current study and as in general across southern Australia from Australia-wide surveys of forage legume root disease (Foster et al. 2017). Given that there is strong public pressure toward reducing pesticide use, particularly in
Europe (Lamichhane et al. 2016), recognition of their ineffectiveness in some situations involving pathogen complexes offers new impetus toward reducing their usage in such situations. However, for the poorest of Mediterranean soil types such as in Australia, the magnitude of the challenge is illustrated in the current study by the fact that two of our field sites had four pathogen groups, five sites had three pathogen groups, and one site had two pathogen groups. Further, all but one site had a mixture of at least one major oomycete and one major fungal pathogen group present. Even more concerning is that from a southern

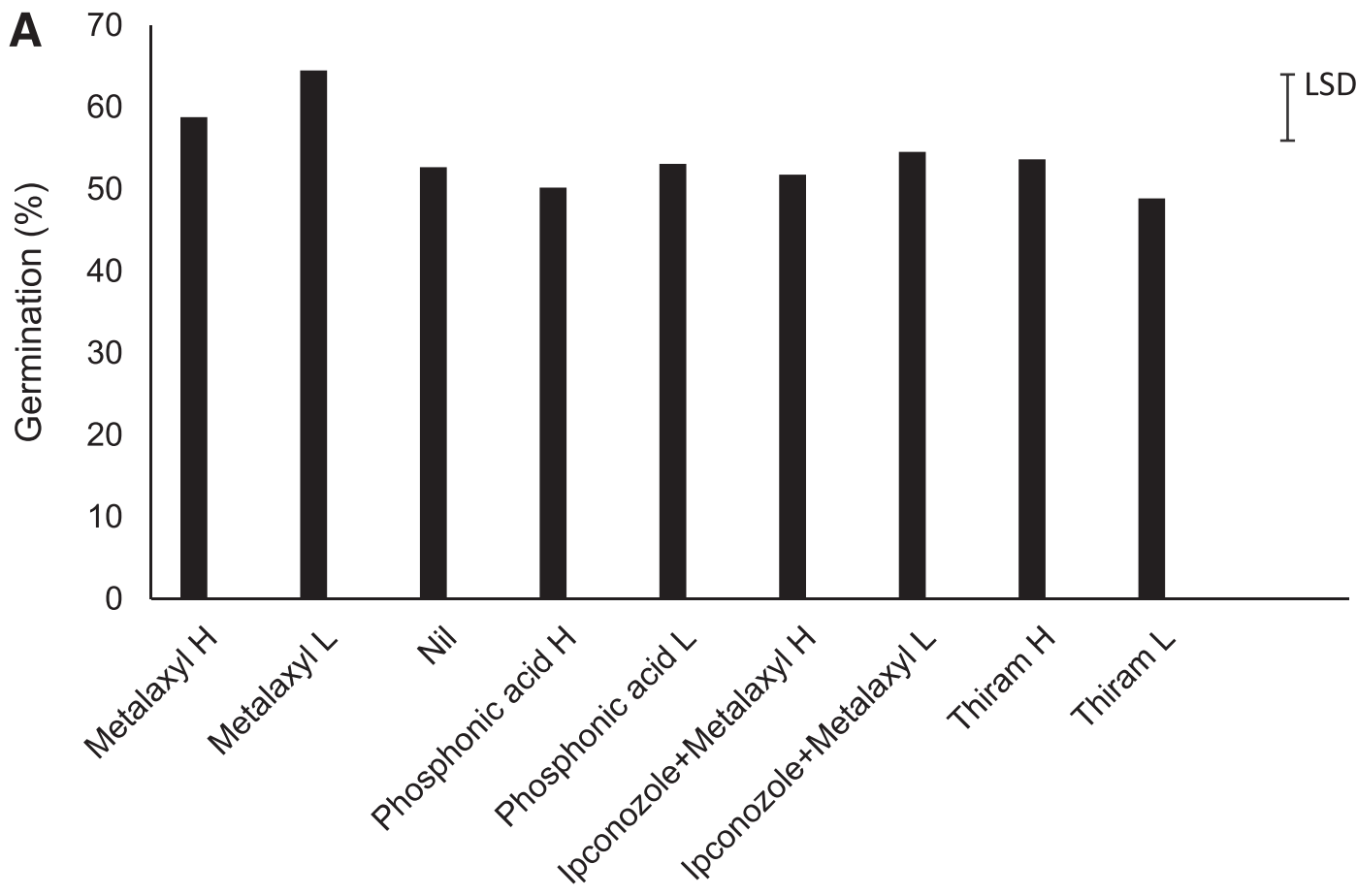

Fungicide seed treatment

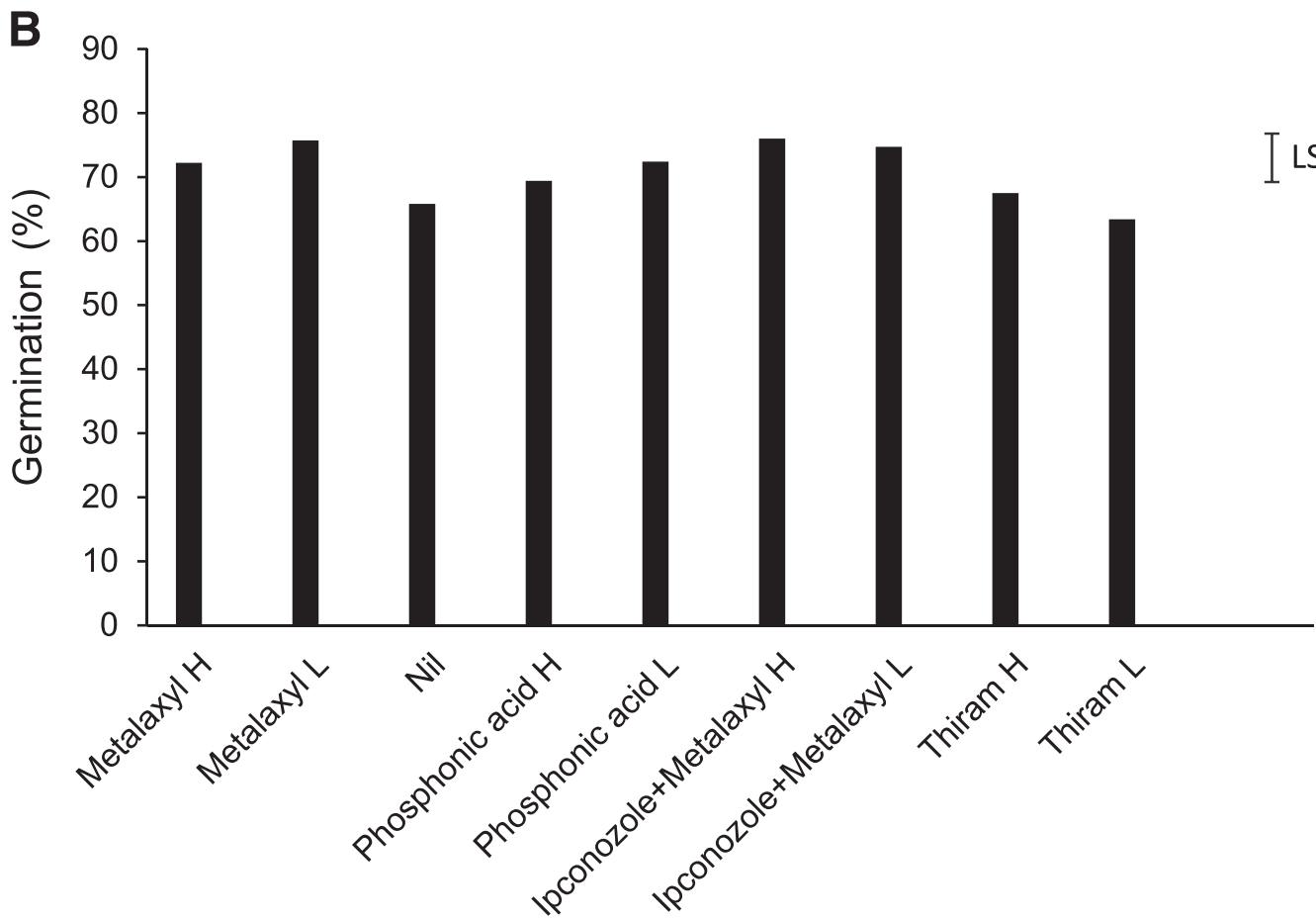

Fungicide seed treatment

Fig. 4. Field studies: Effect of fungicide seed treatments on \% germination. A, South Australia 2015 field site \#2 first sampling. B, New South Wales 2015 field site \#1 first sampling Letters ' $\mathrm{L}$ ' and ' $\mathrm{H}$ ' indicate rates of application at half and at the full manufacturer recommended rate, respectively. 
Australia-wide survey in 2014, Foster et al. (2017) noted the common occurrence of natural synergistic associations in the field between different pathogen genera/species, where combinations of pathogens exceeded the individual incidences for each pathogen occurring solely on its own. For example, Foster et al. (2017) specifically noted examples for Rhizoctonia + Pythium species, Pythium species + Fusarium species, Pythium species $+A$. trifolii, and P. clandestina $+A$. trifolii. Clearly these soilborne pathogens have a preference to operate as complexes under both controlled (e.g., Barbetti et al. 1986a; Wong et al. 1984, 1986a), and in natural field situations (Foster et al. 2017).

We are not suggesting that the Australian situation of complex mixtures of soilborne pathogens involved in devastating forage legumes is universal elsewhere. For example, there is currently no evidence of a similar situation for forage and crop species in Mediterranean (Lamichhane et al. 2018), or even non-Mediterranean regions such as in Europe or the United States where chemical seed treatments are a widely accepted means for providing reliable control of seedling damping-off and/or seedling root diseases (Lamichhane et al. 2018). However, Lamichhane and Venturi (2015) did highlight a concerning trend in general toward increasing synergisms between microbial pathogens in plant disease complexes. One reason for the difference between Australia and elsewhere could be the inherent differences between soil types, even between Australian with European, middle-eastern, and North African Mediterranean climatic regions. The true Mediterranean regions are predominantly a mosaic of soil types characterized by brown earths, brown and red Mediterranean soils, and cinnamon soils (Bridges 1970) that have greater microbial buffering capacity than in the poorer soils of Australia and South Africa that have little biological buffering capacity (Sivasithamparam 1993). For example, Wong et al. (1986a) studied the nature and behavior of $P$. clandestina in the soil and found that exposure of $P$. clandestina inoculum to increasing numbers of soil microbes reduced the severity of root disease of subterranean clover, highlighting that $P$. clandestina is favored by the relatively poor biological buffering capacity of soils in southwest Western Australia. Further, Wong et al. (1986a) demonstrated that the most probable number for $P$. clandestina propagules in a root rot-affected field in Western Australia peaked in May, the month in which root rot is often most severe (Wong et al. 1986b), and coinciding with the opening seasonal rains.

In particular, it is different plant nutrient levels and constituents in these same soils that differentiate the two groups of Mediterranean lands, viz., the moderately fertile soils of the Mediterranean Basin in comparison with the more infertile soils of Australia and South Africa. In these latter two countries, soils have developed from nutrient-poor, very old parent materials or infertile siliceous sands, have been highly weathered, and highly leached, and their levels of macro- and micronutrients have been greatly reduced (Sivasithamparam 1993). As a consequence, soilborne disease complexes are prevalent on annual forage legumes, both in Australia (e.g., Barbetti et al. 2006a, b) and in South Africa (Lamprecht et al. 1988), the latter involving various species of Fusarium such as $F$. avenaceum, $F$. culmorum, $F$. graminearum, and $F$. lateritium, and various Pythium spp. such as $P$. irregulare, $P$. ultimum, and P. spinosum (Lamprecht et al. 1988) and Cylindrocladium scoparium (Lamprecht 1986). The low levels and availability of soil nutrients in Australian and South African soils seemingly prevent any significant role of nutrition in suppression of soilborne diseases (Sivasithamparam 1996). This conclusion is supported by situations where nutrient amelioration of such soils leads to significant reductions in soilborne diseases of forage legumes in Australia (O'Rourke et al. 2012). Clearly, improved management of soilborne diseases by utilizing nutrient amendments is possible, not only by providing the nutrient base to increase activity of resident microbial populations that offer biological buffering against major soilborne diseases, but also through directly enhancing plant growth and defenses. The critical role of soil nutrients in enhancing the biological buffering against major soilborne diseases, in augmenting the expression of host resistance, in altering interactions between host and pathogen and/or antagonists, and their influence on pathogen inoculum carry-over,
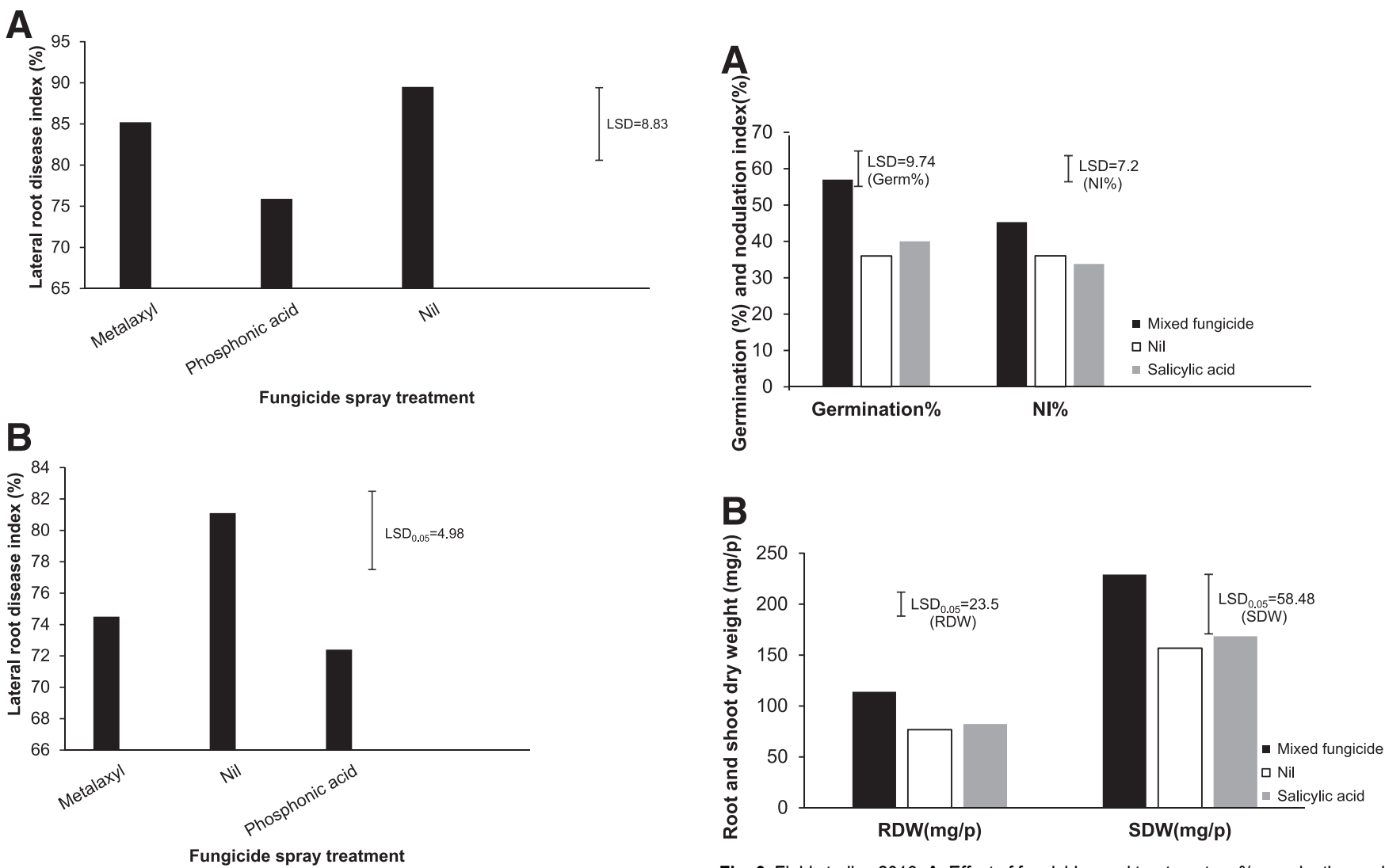

Fig. 5. Field studies 2015 and 2016: Effect of fungicide foliar sprays on \% lateral root disease index. A, New South Wales 2015 field site \#2 second sampling. B, Western Australia 2016 field site \#2 second sampling.

Fig. 6. Field studies 2016: A, Effect of fungicide seed treatment on \% germination and $\%$ nodulation index (NI\%), South Australia 2016 field site \#2 first sampling. B, Effect of fungicide seed treatment on root (RDW) and shoot (SDW) dry weight (mg/p), Western Australia 2016 field site \#1 second sampling. 
are areas offering potential improved management of soilborne pathogen complexes. Additional challenge to successful management of soilborne pathogen complexes is driven by the fact that severity of disease caused by the main individual pathogens $P$. clandestina (You and Barbetti 2017a), R. solani (You and Barbetti 2017b), P. irregulare (You et al. 2017b), and A. trifolii (You et al. 2018), in addition to nutrients, are differentially affected by environmental factors such as temperature, soil moisture and cultivar (You and Barbetti 2017a, 2017b; You et al. 2017b, 2018).

For forage legumes, there seems little if any potential for practical management of damping-off and root disease using fungicide seed and/or foliar spray treatments where soilborne pathogen complexes are involved. While fungicide seed treatment is "frequently performed with almost $100 \%$ of treated seeds for the most important arable crops worldwide" (Lamichhane et al. 2019), there is a need not only for more extensively field test recommended fungicide seed and foliar treatments, but to better 'match' soilborne pathogen identities to the relevant fungicide(s). This lack of understanding and quantification of major biotic stress determinants limiting seed germination and seedling emergence remains part of the information gap noted by Lamichhane et al. $(2017,2018)$.

In conclusion, where unpredictable and ever-changing soilborne pathogen complexes are involved, there is a need to refocus away from fungicides to more effective alternative options. These could include a platform for developing and deploying new host tolerances and resistances (Nichols et al. 2014), along with a range of 'less effective' but 'more flexible' options to reduce severity of damping-off and root disease, such as by increasing the proportion of legume-tograss content, by reducing grazing intensity, by adding Rhizobium (You and Barbetti 2019), by better rotation (Barbetti 1991a), by cultivation (Barbetti and MacNish 1984; You et al. 2017a), and by adding mineral amendments (Barbetti 1990; O'Rourke et al. 2012). It is evident that tested fungicide seed and/or foliar spray treatment options, on their own, simply do not offer an effective mitigation strategy for damping-off and root disease on the annual forage legumes that underpin livestock production across southern Australia.

\section{Acknowledgments}

We thank Kunmei Guo, Robert Creasy, Bill Piasini, John Quealy, Kevin Foster, Daniel Kidd, Peter Skinner, and Paul Wilson from the University of Western Australia for their technical support with these studies. We greatly appreciate the support of eight farmers who allowed field experiments on their properties in both 2015 and 2016. Study design, collection, analysis and interpretation of data, writing the article, and decision to submit this paper were independent of funder. All authors state they have no conflict of interest to declare.

\section{Literature Cited}

Almasudy, A., You, M. P., and Barbetti, M. J. 2015. Influence of fungicidal seed and soil treatments and soil type on severity of root disease caused by Rhizoctonia solani AG-8 on wheat. Crop Prot. 75:40-45.

Barbetti, M. J. 1983. Fungicidal control of damping-off and seedling root rot in subterranean clover. Fungic. Nematicide Tests 38:47.

Barbetti, M. J. 1984a. Seed treatments for control of subterranean clover root rot. Australas. Plant Pathol. 13:43-45.

Barbetti, M. J. 1984b. Ridomil and Benlate soil drenches for control of dampingoff and seedling rot in subterranean clover. Fung. Nematicide Tests 40:120.

Barbetti, M. J. 1985. Apron seed treatments for control of damping-off and seedling root rot in subterranean clover. Fung. Nematicide Tests 41:128-129.

Barbetti, M. J. 1989. Response of Medicago cultivars to fungal root pathogens associated with Trifolium subterraneum. Plant Prot. Quart. 4:1-3.

Barbetti, M. J. 1990. Effect of adding lime to potting soil upon the pathogenicity of four root pathogens on subterranean clover. Phytophylactica 22:245-249.

Barbetti, M. J. 1991a. Effect of clover-free rotations upon the severity of root rot and yield in regenerating subterranean clover pastures. Aust. J. Agric. Res. 42:1195-1204.

Barbetti, M. J. 1991b. Effects of temperature and humidity on diseases caused by Phoma medicaginis and Leptosphaerulina trifolii in lucerne (Medicago sativa). Plant Pathol. 40:296-301.

Barbetti, M. J., and Jones, R. A. C. 2011. Roles of fungal and nematode infections in casing declining pasture health across Australia. Meat and Livestock Australia.

Barbetti, M. J., and MacNish, G. C. 1984. Effects of cultivation and cultural practices on root rot of subterranean clover. Aust. J. Exp. Agric. Anim. Husb. 24:550-554.

Barbetti, M. J., Riley, I. T., You, M. P., Li, H., and Sivasithamparam, K. 2006a. The association of necrotrophic fungal pathogens and plant parasitic nematodes with the loss of productivity of annual medic-based pastures in Australia and options for their management. Australas. Plant Pathol. 35:691-706.

Barbetti, M. J., and Sivasithamparam, K. 1987. Effects of soil pasteurization on root rot, seedling survival and plant dry weight of subterranean clover inoculated with six fungal root pathogens. Crop Pasture Sci. 38:317-327.

Barbetti, M. J., Sivasithamparam, K., Riley, I. T., and You, M. P. 2006b. Role and impact of diseases caused by soil-borne plant pathogens in reducing productivity in southern Australian pasture systems. Meat and Livestock Australia.

Barbetti, M. J., Sivasithamparam, K., and Wong, D. H. 1986a. Root rot of subterranean clover. Rev. Plant Pathol. 65:287-295.

Barbetti, M. J., Sivasithamparam, K., and Wong, D. H. 1987a. Fungicidal drenches for control of root rot in subterranean clover. Plant Soil 101:151-157.

Barbetti, M. J., Sivasithamparam, K., and Wong, D. H. 1987b. Fungicidal seed treatments for control of root rot in subterranean clover. Phytophylactica 19: 57-60.

Barbetti, M. J., Wong, D. H., Sivasithamparam, K., and D’Antuono, M. F. 1986b. Response of subterranean clover cultivars to root rot fungi. Ann. Appl. Biol. 109:259-267.

Barbetti, M. J., You, M. P., Li, H., Ma, X. L., and Sivasithamparam, K. 2007. Management of root diseases of annual pasture legumes in Mediterranean ecosystems - a case study of subterranean clover root diseases in the southwest of Western Australia. Phytopathol. Mediterr. 46:239-258.

Bridges, E. M. 1970. World Soils. The University Press, Cambridge, UK.

Burnett, V. F., Coventry, D. R., Hirth, J. R., and Greenhalgh, F. C. 1994. Subterranean clover decline in permanent pastures in north-eastern Victoria. Plant Soil 164:231-241.

Corbin, E. J., Brockwell, J., and Gault, R. R. 1977. Nodulation studies on chickpea (Cicer aerietinum). Aust. J. Exp. Agric. 17:126-134.

Foster, K., You, M. P., Nietschke, B., Edwards, N., and Barbetti, M. J. 2017. Soilborne root disease pathogen complexes drive widespread decline of subterranean clover pastures across diverse climatic zones. Crop Pasture Sci. 68:33-44.

Gillespie, D. J. 1983. Forage deterioration - causes and cures. J. Agric. W. Aust. 1:3-8.

Greenhalgh, F. C. 1983. Growth cabinet evaluation of fungicides for control of Pythium damping-off and root rot of subterranean clover. Fungic. Nematicide Tests 38:47.

Greenhalgh, F. C., and Clarke, R. G. 1985. The use of fungicides to study the significance and etiology of root rot of subterranean clover in dryland pastures of Victoria. Pages 234-236 in: Ecology and Management of Soilborne Plant Pathogens. C. A. Parker, K. J.Moore, P. T. W. Wong, A. D. Rovira, and J. F. Kollmorgen, eds. American Phytopathological Society, St Paul, MN.

Greenhalgh, F. C., de Boer, R. F., Merriman, P. R., Hepworth, G., and Keane, P. J. 1994. Control of Phytophthora root rot of irrigated subterranean clover with potassium phosphonate in Victoria, Australia. Management of Soil-borne Plant Pathogens. Plant Pathol. 43:1009-1019.

Hochman, Z., Osborne, G. J., Taylor, P. A., and Cullis, B. 1990. Factors contributing to reduced productivity of subterranean clover (Trifolium subterraneum L.) pastures on acidic soils. Aust. J. Agric. Res. 41:669-682.

Kellam, M. K., and Coffey, M. D. 1985. Quantitative comparison of the resistance to Phytophthora root rot in three avocado rootstocks. Phytopathology 75:230-234.

Lamichhane, J. R., Dachbrodt-Saaydeh, S., Kudsk, P., and Messéan, A. 2016. Toward a reduced reliance on conventional pesticides in European agriculture. Plant Dis. 100:10-24.

Lamichhane, J.-R., Debaeke, P., Steinberg, C., You, M. P., Barbetti, M. J., and Aubertot, J.-N. 2018. Abiotic and biotic factors affecting crop seed germination and seedling emergence. Plant Soil 432:1-28.

Lamichhane, J. R., Dür, C., Schwanck, A. A., Robin, M.-H., Sarthou, J.-P., Cellier, V., Messéan, A., and Aubertot, J.-N. 2017. Integrated management of damping-off diseases. A review. Agron. Sustain. Dev. 37:10.

Lamichhane, J. R., and Venturi, V. 2015. Synergisms between microbial pathogens in plant disease complexes: A growing trend. Front. Plant Sci. 6.

Lamichhane, J.-R., You, M. P., Laudinot, V., Byamukama, E., Barbetti, M. J., and Aubertot, J.-N. 2019. Revisiting the sustainability of fungicide seed treatments for field crops. Plant Dis. doi.org/10.1094/PDIS-06-19-1157-FE.

Lamprecht, S. C. 1986. A new disease of Medicago truncatula caused by Cylindrocladium scoparium. Phytophylactica 18:111-114.

Lamprecht, S. C., Knox-Davies, P. S., and Marasas, W. F. O. 1988. Fungi associated with root rot of annual Medicago spp. in South Africa. Phytophylactica 20:281-286.

Li, Y. P., You, M. P., Colmer, T. D., and Barbetti, M. J. 2014. Species of Pythium associated with seedling root and hypocotyl disease on common bean (Phaseolus vulgaris) in Western Australia. Plant Dis. 98:1241-1247.

Ma, X., Li, H., O'Rourke, T., Sivasithamparam, K., and Barbetti, M. J. 2008. Cooccurrence of an Aphanomyces sp. and Phytophthora clandestina in subterranean clover pastures in the high rainfall areas of the lower south-west of Western Australia. Australas. Plant Pathol. 37:74-78.

McKinney, H. H. 1923. A new system of grading plant diseases. J. Agric. Res. 26: 195-218.

Nicholas, D. A. 1985a. Dalkeith and Junee subterranean clovers. Department of Agriculture, Western Australia, Farmnote 14/85.

Nicholas, D. A. 1985b. Green Range and Karridale subterranean clovers. Department of Agriculture, Western Australia, Farmnote 19/85. 
Nichols, P. G. H., Jones, R. A. C., and Barbetti, M. J. 2014. Genetic improvement of subterranean clover (Trifolium subterraneum L.). 2. Breeding for disease and pest resistance. Crop Pasture Sci. 65:1207-1229.

O’Rourke, T. A., Ryan, M. H., Li, H., Ma, X. L., Sivasithamparam, K., Fatehi, J., and Barbetti, M. J. 2010. Taxonomic and pathogenic characteristics of a new species Aphanomyces trifolii causing root rot of subterranean clover (Trifolium subterraneum) in Western Australia. Crop Pasture Sci. 61: 708-720.

O'Rourke, T. A., Ryan, M. H., Scanlon, T. T., Sivasithamparam, K., and Barbetti, M. J. 2012. Amelioration of root disease of subterranean clover (Trifolium subterraneum) by mineral nutrients. Crop Pasture Sci. 63:672-682.

O'Rourke, T. A., Scanlon, T. T., Ryan, M. H., Wade, L. J., McKay, A. C., Riley, I. T., Li, H., Sivasithamparam, K., and Barbetti, M. J. 2009. Severity of root rot in mature subterranean clover and associated fungal pathogens in the wheatbelt of Western Australia. Crop Pasture Sci. 60:43-50.

Pfender, W. F., Delwiche, A., Grau, C. R., and Hagedorn, D. J. 1984. A medium to enhance recovery of Aphanomyces from infected plant tissue. Plant Dis. 68: 845-847.

Schwinn, F. J., Staub, T., and Urech, P. A. 1977. A new type of fungicide against diseases caused by oomycetes. Medelelingen van de Faculteit van de Landbouwwetenschappe. Rijksuniv. Gent 42:1181-1188.

Sivasithamparam, K. 1993. Ecology of root-infecting pathogenic fungi in Mediterranean environments. Adv. Plant Pathol. 10:245-279.

Sivasithamparam, K. 1996. The effect of soil nutrients on microbial suppression of soil-borne diseases. Pages 123-145 in: Management of Soil Borne Diseases. R. S. Utkhede and V. K. Guptaed, eds. Kalyani Publishers, Ludhiana, India.

Smiley, R. W., Taylor, P. A., Clarke, R. G., Greenhalgh, F. C., and Trutmann, P. 1986. Simulated soil and plant management effects on root rots of subterranean clover. Aust. J. Agric. Res. 37:633-645

Taylor, P. A., Barbetti, M. J., and Wong, D. H. 1985a. Occurrence of Phytophthora clandestina in Western Australia. Plant Prot. Q. 1:57-58.

Wong, D. H. 1986. Fungi associated with root rot of subterranean clover in southwest of Western Australia. Ph.D. thesis. University of Western Australia.

Wong, D. H., Barbetti, M. J., and Sivasithamparam, K. 1984. Effects of soil temperature and moisture on the pathogenicity of fungi associated with root rot of subterranean clover. Aust. J. Agric. Res. 35:675-684.

Wong, D. H., Barbetti, M. J., and Sivasithamparam, K. 1985a. Pathogenicity of Rhizoctonia spp. associated with root rots of subterranean clover. Trans. Br. Mycol. Soc. 85:156-158.

Wong, D. H., Barbetti, M. J., and Sivasithamparam, K. 1985b. Fungi associated with root rots of subterranean clover in Western Australia. Aust. J. Exp. Agric. 25:574-579.
Wong, D. H., D'Antuono, M. F., Barbetti, M. J., and Sivasithamparam, K. 1986a Inter-relationship between shoot weight, severity of root rot and survival rate of subterranean clover inoculated with certain pathogenic fungi. Plant Soil 96: 141-143.

Wong, D. H., Barbetti, M. J., and Sivasithamparam, K. 1986b. Behaviour of Phytophthora clandestina propagules at a field site in Western Australia. Aust. J. Soil Res. 24:483-491.

You, M. P., and Barbetti, M. J. 2017a. Severity of Phytophthora root rot and preemergence damping-off in subterranean clover influenced by moisture, temperature, nutrition, soil type, cultivar and their interactions. Plant Pathol. 66:1162-1181.

You, M. P., and Barbetti, M. J. 2017b. Environmental factors determine severity of Rhizoctonia damping-off and root rot in subterranean clover. Australas. Plant Pathol. 46:357-368.

You, M. P., and Barbetti, M. J. 2019. Manipulating the ecosystem enables management of soilborne pathogen complexes in annual legume forage systems. Plant Pathol. 68:454-469.

You, M. P., Barbetti, M. J., and Nichols, P. G. H. 2005a. New sources of resistance identified in Trifolium subterraneum breeding lines and cultivars to root ro caused by Fusarium avenaceum and Pythium irregulare and their relationship to seedling survival. Australas. Plant Pathol. 34:237-244.

You, M. P., Barbetti, M. J., and Sivasithamparam, K. 2005b. Characterization of Phytophthora clandestina races on Trifolium subterraneum in Western Australia. Eur. J. Plant Pathol. 113:267-274.

You, M. P., Guo, K. M., Nichol, D., Kidd, D., Ryan, M., Foster, K., and Barbetti, M. J. 2017a. Cultivation offers effective management of subterranean clover damping-off and root disease. Grass Forage Sci. 72:785-793.

You, M. P., Lancaster, B., Sivasithamparam, K., and Barbetti, M. J. 2008. Crosspathogenicity of Rhizoctonia solani strains on pasture legumes in pasture-crop rotations. Plant Soil 302:203-211.

You, M. P., O’Rourke, T. A., Foster, K., Snowball, R., and Barbetti, M. J. 2016. Host resistances to Aphanomyces trifolii root rot of subterranean clover: First opportunity to successfully manage this severe pasture disease. Plant Pathol. 65:901-913.

You, M. P., Rensing, K., Renton, M., and Barbetti, M. J. 2017b. Modelling effects of temperature, soil, moisture, nutrition and variety as determinants of severity of Pythium damping-off and root disease in subterranean clover. Front. Microbiol. 8:2223.

You, M. P., Rensing, K., Renton, M., and Barbetti, M. J. 2018. Critical factors driving Aphanomyces damping-off and root disease in clover revealed and explained using linear and generalized linear models and boosted regression trees. Plant Pathol. 67:1374-1387. 